\title{
ANALISIS IMPLEMENTASI TOTAL QUALITY MANAGEMENT (TQM): STUDI PADA LEMBAGA AMIL ZAKAT SELURUH INDONESIA
}

\author{
Oleh: \\ Sri Fadilah \\ Yuni Rosdiana \\ Edi Sukarmanto \\ Dadan H Ilyas \\ (Program Studi Akuntansi Unisba)
}

\begin{abstract}
Abstrak
Di Indonesia sekarang ini, perkembangan organisasi non pemerintah seperti Lembaga Amil Zakat yang mengelola dana zakat, infak dan shadaqah demikian menjamur sebagai gerakan sosial (civil society). Realitasnya, terjadi gap antara potensi zakat yang besar (20 triliun) dengan realisasi zakat yang sangat kecil (1 triliun). Fenomena tersebut menunjukkan masih rendahnya kinerja Organisasi Pengelola Zakat (OPZ) khususnya Lembaga Amil Zakat (LAZ). Tuntutan tersebut menjadi tantangan bagi LAZ untuk melakukan tata kelola yang baik (good governance). Selanjutnya akan berdampak pada tuntutan masyarakat yang tinggi akan akuntabilitas dan transparansi dari LAZ. Kemudian menjadi tantangan bagi LAZ untuk melakukan berbagai upaya dalam rangka meningkatkan kinerja OPZ khususnya LAZ terutama penghimpunan dana zakat. Hasil penelitian ini diharapkan menjadi referensi bagi pengembangan pengelolaan (good governance) pengendalian intern yang diimplementasikan. Sesuai tujuan penelitian ini maka variabel yang diteliti adalah total quality management (TQM). Adapun tujuan penelitian ingin melihat implementasi total quality management (TQM) pada Lembaga Amil Zakat Seluruh Indonesia. Metode penelitian yang digunakan analisis kualitatif deskriptif, dengan teknik pengumpulan data terdiri dari: observasi, wawancara dan dokumentasi.
\end{abstract}

Kata Kunci: Total Quality Management, Zakat dan Lembaga Amil Zakat

\section{Latar Belakang}

Rukun Islam merupakan pilar dalam tatanan peribadatan pada ajaran Islam. Sebagai pilar peribadatan, Rukun Islam merupakan kewajiban bagi pemeluk agama Islam. Salah satu kewajiban yang terkandung dalam rukun Islam (rukun Islam ketiga) adalah kewajiban membayar zakat. Kewajiban membayar zakat bagi umat Islam mengandung dua dimensi fundamental (utama), yaitu Pertama, sebagai dimensi ibadah (ritual) yang merupakan wujud penghambaan kepada Allah SWT (hablumminallah) dan juga sebagai media untuk membersihkan harta atau kekayaan dan jiwa manusia. Kedua, merupakan dimensi sosial sebagai wujud kepedulian terhadap sesama manusia dan lingkungan (habluminannas), sehingga dapat dimanfaatkan untuk mengatasi berbagai permasalahan sosial, khususnya kesenjangan sosial, diamana terjadi gap atau kesenjangan yang semakin lebar antara masyarakat mampu (kaya) dengan masyarakat yang tidak mampu (miskin). Dalam istilah lain bahwa "zakat merupakan rukun sosial yang nyata di antara semua rukun islam", sehingga zakat termasuk kewajiban sosial yang bersifat ibadah (Djailani,2003). Begitu pentingnya kewajiban membayar zakat, sehingga Allah mensejajarkan kewajiban membayar zakat dengan kewajiban menunaikan sholat (rukun 
islam kedua) yang berdimensi transendental (habluminnaanas). Hal tersebut sesuai dengan Firman Allah dalam Al Qur-an pada surat Al-Baqarah ayat 43.

Di sisi lain, terdapat beberapa firman Allah dalam Al Quran dalam surat yang berbeda seperti dalam surat $\mathrm{Al}$ Imran ayat 92 dan ayat 134 yang menjelaskan perintah menunaikan sholat selalu diiringi dengan kewajiban membayar zakat, yang kedua perintah tersebut sebagai wujud atau bukti dari ketaqwaan manusia kepada Allah. Kesejajaran ajaran tersebut merupakan kombinasi yang harmonis peribadatan dalam Islam yaitu habluminallah dan habluminannas. Artinya ibadah yang sempurna bagi manusia adalah manakala terdapat keharmonisan dan keserasian antara ibadah secara vertikal kepada Allah dan secara horizontal kepada sesama manusia.

Selanjutnya, kesejajaran kewajiban menunaikan sholat dan membayar zakat dijelaskan dalam surat lain dalam Al Qur'an yaitu Al Baqarah ayat 110 dimana dijelaskan bagaimana melaksanakan sholat dan membayar zakat mengandung banyak kebaikankebaikan.

Dari berbagai penjelasan tentang membayar zakat, maka zakat adalah ibadah maaliyah ijtima'iyyah yang memiliki posisi yang sangat strategis, baik dari sisi ajaran maupun dari sisi pembangunan kesejahteraan umat. Sebagai suatu ibadah utama, kewajiban membayar zakat merupakan salah satu rukun Islam, sebagaimana diungkapkan dalam berbagai hadits nabi, sehingga keberadaan rukun Islam dianggap sebagai ma'lum min al-dien bi al-dharurah atau diketahui secara otomatis adanya dan merupakan bagian mutlak keislaman seseorang (umat Islam).

Selanjutnya Allah berfirman dalam Al Qur'an bahwa berzakat dipandang sebagai indikator utama kedudukan seseorang terhadap ajaran Islam, ciri orang takwa, ciri mukmin yang akan mendapatkan kebahagiaan hidup, ciri utama mukmin yang akan mendapatkan pertolongan Allah, dan keadaan seseorang membayar zakat (dalam keadaan lapang dan sempit). Membayar zakat dipandang pula sebagai upaya seseorang yang selalu berkeinginan untuk membersihkan diri dan jiwa dari berbagai sifat buruk seperti bakhil, egois dan tamak, juga sekaligus berkeinginan untuk selalu membersihkan, mensucikan dan mengembangkan harta yang dimilikinya.

Zakat adalah salah satu pilar penting dalam Rukun Islam. Pentingnya kedudukan zakat dapat dilihat dalam kitab Suci Al- Qur'an yang selalu mengiringi perintah zakat dengan perintah shalat. Hal ini menunjukkan hikmah yang sangat besar. Jika shalat adalah sarana komunikasi dengan sang Khalik, maka zakat adalah sarana komunikasi dan sosialisasi antar manusia. Selanjutnya, jika zakat diorganisir secara baik dan orang kaya menyadari bahwa zakat itu adalah suatu pengeluaran wajib dari harta bendanya yang diperintahkan oleh aqidah dan kekuatan hukum, niscaya dana jaminan sosial akan mempunyai suatu sumber yang penting dan mendalam, di samping sumber lainnya. Artinya, apabila dikelola dengan profesional zakat akan mampu mengatasi masalah kemiskinan.

Kewajiban menunaikan zakat yang sedemikian tegas dan mutlak itu, oleh karena di dalam ajaran terkandung hikmah dan manfaat yang demikian besar dan mulia, baik yang berkaitan dengan muzaki (orang yang wajib zakat), mustahiq (orang yang berhak atas zakat), harta benda yang dikeluarkan zakatnya, maupun bagi masyarakat secara keseluruhan. Adapun hikmah dan manfaat menunaikan zakat antara lain sebagai berikut: (1) Sebagai perwujudan keimanan kepada Allah SWT, mensyukuri nikmatnya, menumbuhkan akhlak mulia dengan memiliki rasa kepedulian yang tinggi, menghilangkan sifat kikir dan rakus, menumbuhkan ketenangan hidup, sekaligus mengembangkan dan mensucikan harta yang dimiliki; (2) Zakat berfungsi untuk menolong, membantu dan membina mereka terutama golongan fakir miskin ke arah kehidupan yang lebih baik dan lebih sejahtera, sehingga mereka dapat memenuhi 
kebutuhan hidupnya dengan layak, dapat beribadah kepada Allah SWT, terhindar dan bahaya kekufuran sekaligus menghilangkan sifat iri dan dengki. Karena zakat bukan sekedar memenuhi kebutuhan bersifat konsumtif yang sifatnya sesaat, tetapi memberikan kecukupan dan kesejahteraan, dengan cara menghilangkan atau memperkecil penyebab kehidupan mereka menjadi lebih miskin dan menderita; (3) Sebagai pilar amal jama'i antara kelompok aghniya yang berkecukupan hidupnya, dengan para mujahid yang semua waktunya dipergunakan untuk berjuang di jalan Allah, sehingga tidak memiliki waktu yang cukup untuk berusaha bagi kepentingan nafkah diri dan keluarganya; (4) Sebagai salah satu sumber dana bagi pembangunan sarana maupun prasarana yang harus dimiliki oleh umat islam, seperti sarana pendidikan, kesehatan, sosial maupun ekonomi. Dan terlebih bagi kepentingan peningkatan kualitas sumber daya manusia; (5) Untuk memasyarakatkan etika bisnis yang benar, karena zakat tidak akan diterima dari harta yang didapatkan dengan cara yang batil. Zakat mendorong pula umat Islam untuk menjadi muzaki yang sejahtera hidupnya.

Selanjutnya dalam pelaksanaan zakat harus sesuai dengan ajaran agama, sebagaimana dijelaskan dalam surat At-Taubah ayat 60 , disebutkan orang-orang atau badan yang berhak menerima zakat diklasifikasikan ke dalam delapan asnaf, yaitu sebagai berikut: (1) Fakir, yaitu orang-orang yang tidak memiliki apa-apa untuk memenuhi kebutuhan primer hidupnya; (2) Miskin, yaitu orang yang mempunyai harta namun tidak cukup untuk memenuhi kebutuhan primer hidupnya; (3) Amilin (petugas zakat), yaitu para petugas zakat baik yang bertugas mengambil zakat maupun yang bertugas mendistribusikan dan mendayagunakannya; (4) Mu'alaf yaitu orang-orang yang hatinya telah takluk, dikarenakan bantuan muslimin, berhenti dari mengganggu kaum muslimin, tertarik kepada Islam, serta anjuran kaumnya dan keluarganya untuk masuk Islam; (5) Para budak, yaitu orang-orang yang ingin membebaskan dirinya dari tuannya; (6) Orang-orang yang berhutang (gharim), untuk kepentingan dirinya dan kepentingan kaum muslimin; (7) Fisabilillah, yaitu tentara yang berjihad di jalan Allah. Ibnu Sabil, yaitu musafir yang kehabisan bekal dalam perjalanannya.

Beberapa tahun terakhir ini di Indonesia, isu yang berkaitan dengan konsep pelaksanaan zakat baik sebagai kewajiban agama secara pribadi maupun zakat sebagai komponen keuangan publik sangat populer. UU No. 38 tahun 1999 tentang Pengelolaan Zakat menjadi payung hukum yang lebih kuat dalam pengelolaan zakat di Indonesia, sebagai upaya untuk mendukung fakta bahwa Indonesia adalah negara yang penduduk muslimya terbesar di dunia, yaitu berjumlah $80 \%$ dari sekitar 220 juta penduduk Indonesia adalah sebesar 180 juta penduduk muslim (Eri Sudewo:2008) yang memiliki kewajiban menunaikan zakat baik zakat fitrah dan zakat harta. Kondisi tersebut semestinya menjadi potensi zakat yang luar biasa berkaitan dengan upaya penghimpunan zakat. Di bawah ini disajikan potensi zakat yang dapat dihimpun, yaitu:

Tabel 1.1

Potensi Zakat di Indonesia

\begin{tabular}{|l|l|l|l|}
\hline \multicolumn{1}{|c|}{ Keterangan } & Potensi Zakat & \multicolumn{1}{|c|}{ Keterangan } & Potensi Zakat \\
\hline $\begin{array}{l}\text { PIRAC (Kompas } \\
\text { 2008) }\end{array}$ & Rp 9,09 trilyun & $\begin{array}{l}\text { Direktur Thoha Putra } \\
\text { Center Semarang,(2009) }\end{array}$ & Rp 100 triliun \\
\hline $\begin{array}{l}\text { UIN Syarif } \\
\text { Hidayatullah(2004) }\end{array}$ & Rp 19,3 trilyun & Baznas (Republika:2005) & Rp 19,3 triliun \\
\hline $\begin{array}{l}\text { Adiwarman \&. Azhar } \\
\text { Syarief 2009) }\end{array}$ & Rp 20 triliun & FoZ (Forum Zakat:2009) & Rp 20 triliun \\
\hline
\end{tabular}

Dengan banyak berdirinya lembaga amil zakat yang sekarang berjumlah 400 LAZ (FoZ.2011), dapat dijadikan sebagai alternatif bagi masyarakat dalam menyalurkan dana zakatnya selain kepada Badan Amil Zakat yang berjumlah 50.956 (Baznas.2009). 
Selain itu Lembaga Amil Zakat ini pada akhirnya dapat diharapkan sebagai media untuk menjembatani dalam pencapaian potensi zakat di Indonesia. diperkirakan masih terdapat sekitar $600 \mathrm{OPZ}$ baik LAZDA maupun UPZ yang telah berdiri baik yang berbasis masjid maupun perusahaan yang tidak atau belum terdaftar pada FoZ (Forum Zakat). Namun demikian, berkembangnya lembaga pengelola zakat (BAZ/LAZ), sampai saat ini belum disertai dengan minat masyarakat untuk membayar zakat pada lembaga zakat tersebut. Dampaknya adalah belum optimalnya pengelolaan zakat di Indonesia. Hal tersebut sangat disayangkan karena betapa besarnya potensi zakat di Indonesia, jika tidak dikelola dengan baik. Tabel 1.2 menyajikan data yang berkaitan dengan realisasi penghimpunan zakat:

Tabel 1.2

Realisasi Penghimpunan Zakat

\begin{tabular}{|c|l|l|}
\hline No & \multicolumn{1}{|c|}{ Keterangan } & \multicolumn{1}{c|}{ Jumlah } \\
\hline 1 & Data dari Depag (2007) & BAZ: Rp 12 miliar dan LAZ: Rp 600 miliar \\
\hline 2 & Data Depag (2008) & BAZ dan LAZ: Rp 900 miliar \\
\hline 3 & Forum Zakat (FoZ) (2009) & LAZ dalam data FoZ: Rp 900 miliar \\
\hline 4 & IZDR (2004-2008) & Rp 61,3 miliar menjadi Rp 361 milyar \\
\hline
\end{tabular}

Berdasarkan dari fenomena tersebut, hal lain yang yang harus dicermati adalah kenyataannya dengan adanya UU pengelolaan zakat, dan banyak berdirinya lembaga amil zakat ternyata belum berdampak pada kesadaran masyarakat untuk menyalurkan zakatnya pada lembaga pengelola zakat (BAZ/LAZ) pada yang semakin meningkat terhadap pentingnya berzakat. Berdasarkan hasil riset PIRAC terdapat 29 juta keluarga sejahtera yang menjadi warga sadar zakat. Di sisi lain saat ini, diperkirakan hanya ada sekitar 12 13 juta muzaki yang membayar zakat lewat LAZ, berarti masih ada lebih dari separuh potensi zakat yang belum tergarap oleh LAZ. Gambaran tersebut harus dipandang sebagai tantangan bagi lembaga pengelola zakat khususnya LAZ untuk memperbaiki kinerjanya khususnya berkaitan dengan penghimpunan dana zakat. Tantangan tersebut harus disikapi sebagai upaya perbaikan bagi LAZ untuk lebih profesional dalam melakukan kegiatannya.Tujuan khusus riset ini adalah ingin melihat pengeloaan zakat, dengan segala ketentuannya dan dampaknya pada kinerja LAZ. Karena jika dana zakat pada LAZ dikelola dengan baik semestinya mampu mengangkat harkat dan martabat kaum yang tertinggal, namun kenyataannya potensi tersebut hanya angan-angan belaka. Padahal Indonesia sebagai sebuah negara, yang memiliki potensi yang sangat besar dan strategis dalam pengumpulan zakat, di mana Indonesia penduduknya sebagian besar muslim. Jelaslah bahwa zakat seyogyanya dapat dijadikan sebagai sumber pendapatan bagi pemerintah untuk mengentaskan kemiskinan. Berkaitan dengan kemiskinan, di bawah ini tersaji data tentang penduduk miskin Indonesia baik dalam jumlah maupun presentase sebagai berikut

Tabel 1.3

Jumlah dan Persentase Penduduk Miskin di Indonesia

\begin{tabular}{|c|c|c|}
\hline Tahun & Jumlah Penduduk Miskin (Juta) & Persentase Penduduk Miskin \\
\hline 2006 & 39,30 & $17,75 \%$ \\
\hline 2007 & 37,17 & $16,58 \%$ \\
\hline 2008 & 41,70 & $21,92 \%$ \\
\hline
\end{tabular}

Sumber: Diolah dari data Survei Sosial Ekonomi Nasional (Susenas)

Kemudian, meskipun keberadaan organisasi pengelola zakat yang semakin banyak di Indonesia, namun jika umat Islam selama ini membayar atau menunaikan zakat tidak secara lembaga seperti membayar zakat dengan menyerahkan kepada sanak keluarga terdekat, maka upaya mencapai potensi zakat masih akan tidak tercapai. Sistem pembayaran zakat tersebut bukan berarti jelek atau tidak baik namun dampak sosialnya 
sempit dan bersifat jangka pendek. Akan berbeda dengan pembayaran zakat secara lembaga dan sistematis, seperti membayar zakat kepada lembaga zakat baik BAZ dan LAZ akan berdampak luas karena dana zakat akan dikelola dalam bentuk programprogram sosial yang terarah dan terstruktur dan dampak sosialnya bersifat jangka panjang. Adapun urgensi penelitian ini, dengan melihat berbagai masalah yang disinyalir menjadi penghalang mengapa potensi zakat di Indonesia yang sangat besar tersebut belum terkelola dengan baik dan optimal sehingga berdampak pada kinerja Oragnisasi Pengelola Zakat (OPZ) khususnya LAZ masih rendah. Adapun masalah tersebut dari berbagai sumber disajikan sebagai berikut: (a) Badan pengelola zakat dianggap tidak profesional karena belum menerapkan prinsip akuntabilitas dan transparansi (Almisar Hamid.2009:10); (b) Pengelola dana zakat dianggap belum memiliki sumber daya manusia (SDM) yang kualitasnya optimal, yaitu berkompeten (kaffah), amanah, dan memiliki etos kerja tinggi (himmah) (Jamil Azzaini.2008:9); (c) Sistem birokrasi dan good governance masih lemah berkaitan dengan pengelolaan zakat di Indonesia sehingga berdampak pada rendahnya akuntabilitas dan transparansi LAZ (Asep Saefuddin Jahar:2006:7).

Selain penyebab permasalahan belum optimalnya pengelolaan zakat akan berdampak pada belum cukup baiknya kinerja yang dicapai OPZ khusus LAZ, Permasalahan lain yang perlu untuk diperbaiki berdasarkan (survey CID dompet Dhuafa dan LKIHI-FHUI:2008:11-16) telah terrangkum ke dalam tujuh permasalahan utama, yaitu: (1) Permasalahan Kelembagaan, (2) Permasalahan Peraturan Perundang-undangan, (3) Pengumpulan, pendistribusian dan pendayagunaan zakat, (4) Pengawasan dan Pelaporan, (5) Korelasi Zakat dengan Pajak, (6) Peran Serta Masyarakat dan (7) Sanksi dan Sengketa Zakat.

Dari uraian permasalahan yang selama ini yang disinyalir sebagai kendala dalam pengelolaan zakat di Indonesia, menunjukkan kendala yang sangat kompleks. Hal tersebut berawal dari ketidakpercayaan masyarakat terhadap lembaga pengelola zakat (LAZ) tersebut (CID Dompet Dhuafa dan LKIHI-FHUI:2008:19-20). Untuk mendukung hal tersebut, harus diciptakan pengelolaan perusahaan yang baik dan optimal hingga dapat mencapai kinerja yang baik. Salah satu pilar organisasi yang harus diterapkan dalam rangka meningkatkan kinerja LAZ yaitu mendisain dan mengimplementasikan total quality management (TQM).

Selanjutnya, salah satu model yang bisa diterapkan untuk mendukung upaya pencapaian potensi zakat di Indonesia adalah dengan mengimplementasikan model Total Quality Management (TQM). Total Quality Management merupakan suatu model manajemen dalam menjalankan usaha untuk mewujudkan pengelolaan organisasi melalui perbaikan terus-menerus atas produk, jasa, manusia, proses dan lingkungannya yang berakibat pada semakin baiknya kinerja organisasi. Menurut Samdin (2002:19) terdapat beberapa alasan mengapa Total Quality Management perlu diterapkan dalam pengelolaan zakat oleh LAZ diantaranya: (1) untuk dapat meningkatkan daya saing dan unggul dalam persaingan, (2) menghasilkan output/kinerja LAZ yang terbaik, (3) meningkatkan kepercayaan muzaki, dan (4) melakukan perbaikan kualitas pengelolaan dana zakat sehingga dapat meningkatkan kepuasan konsumen. Hal tersebut senada dengan riset Hoque Zahirul (2003:563), yaitu terdapat pengaruh implementasi total quality management terhadap kinerja organisasi.

Berdasarkan latar belakang penelitian di atas, maka urgensi penelitian ini adalah untuk melihat dan menganalisis bagaimana implementasi total quality management (TQM) pada Lembaga Amil Zakat seluruh Indonesia.

Jurnal Akuntansi Riset, Prodi Akuntansi UPI, Vol. 4 No. 1 


\section{Kerangka Pemikiran}

Sejak tahun 1980, telah banyak perusahaan di dunia menyadari adanya kebutuhan untuk melakukan fokus ulang terhadap perspektif kualitas mereka tentang pentingnya total quality management (TQM) dalam persaiangan dan bisnis. Kualitas tidak dapat dilihat dalam satu sisi saja atau dalam ukuran yang sempit, tetapi kualitas harus meliputi seluruh aspek organisasi. Dalam hal ini, keberhasilan organisasi terletak pada kemampuannya untuk menghasilkan produk atau jasa yang memadai yaitu profitable dengan biaya yang minimum (efisiensi).

Nama total quality management pertama kali dikemukakan oleh Nancy Warren, seorang Behavior Scientist di United States Navy. Istilah total mengandung makna every process, every job, dan every person. TQM merupakan sistem manajemen yang berfokus pada orang atau tenaga kerja, bertujuan untuk terus menerus meningkatkan nilai (value) yang dapat memberikan kepada pelanggan dengan biaya penciptaan nilai yang lebih rendah dari nilai tersebut. TQM adalah filosofi manajemen yang mempunyai tujuan utama bagi kepuasan pelanggan untuk barang dan jasa. Tujuan ini hanya dapat dicapai melalui keterlibatan manajemen pada seluruh tingkatan, perbaikan yang berkelanjutan (continuous improvement) dari produk, jasa dan proses, pendidikan dan latihan bagi karyawan dan pertisipasi dari seluruh karyawan dalam pemecah masalah.

Total quality management (TQM) meruapakan suatu terobosan terbaru di bidang manajemen yang seluruh aktivitasnya ditujukan untuk mengoptimalkan kepuasan pelanggan melalui perbaikan proses yang berkesinambungan. TQM merupakan aktivitas yang menyeluruh terhadap pengelolaan mutu. Lebih lanjut Cascio (1995:18) mengemukakan, "TQM , A philosophy and a set guiding principles that represent the foundation of a continuosly improving organization". Begitu juga dengan Robbins (1996:13) mengemukakan bahwa: "TQM, a philosophy of management that is driven by the constant attainment of customer satisfaction through the contonuous improvement of all organizational process"

Pendapat-pendapat di atas menunjukkan dengan jelas bahwa TQM merupakan aktivitas yang ditujukan untuk memenuhi harapan pelanggan. Tujuannya adalah meningkatkan organisasi untuk menghilangkan pemborosan (waste), menyederhanakan proses dan berfokus pada penggunaan praktek mutu yang pada kahirnya akan mempengaruhi setiap aktivitas manajemen, sehingga dicapai kepuasan pelanggan dan perusahaan dapat mencapai keunggulan kompetitif.

Gunarianto (2005:41) mencoba menjelaskan pengertian TQM dari kata-kata yang membentuknya, yaitu total, quality dan management. Secara garis besar, kedua penulis tersebut mendefinisikan TQM sebagai konsep perbaikan yang dilakukan secara terus menerus, yang melibatkan semua karyawan di setiap jenjang organisasi melalui proses manajemen. Lebih rinci, definisi TQM dapat diuraikan sebagai berikut: (a) Pengertian Total: menunjukkan bahwa TQM merupakan srategi organisasional menyeluruh yang melibatkan semua jenjang dan jajaran manajemen dan karyawan. Setiap orang dalam organisasi tersebut terlibat dalam proses TQM. Lebih lanjut kata "total", berarti bahwa TQM mencakup tidak hanya pengguna akhir dan pembeli eksternal saja, tetapi juga pelanggan internal pemasok bahkan personalia pendukung; (b) Pengertian Quality: Kualitas ini bukan berarti sekedar produk bebas cacat, tetapi TQM lebih menekankan pada pelayanan berkualitas. Kualitas didefinisikan oleh pelanggan, bukan organisasi atau manajer departemen pengendali kualitas. Kenyataan bahwa ekspektasi pelanggan bersifat individual, tergantung pada latar belakang sosial-ekonomis dan karakteristik demografis, mempunyai implikasi penting: kualitas bagi seorang pelanggan mungkin tidak sama bagi pelanggan lain. Tantangan TQM adalah menyajikan kualitas bagi semua pelanggan; (c) Pengertian Management: mengandung arti bahwa TQM merupakan pendekatan 
manajemen, bukan pendekatan teknis pengendalian kualitas yang sempit. Pendekatan TQM sangat berorientasi pada manajemen orang. Implementasi TQM mensyaratkan berbagai perubahan organisasional, manajerial total dan fundamental, yang mencakup visi, orientasi strategik dan berbagai praktik manajemen lainnya.

Untuk dapat memenangkan persaingan suatu lembaga baik profit maupun non profit harus mampu memberikan kualitas output perusahaan yang tinggi dimana pada akhirnya dapat memuaskan konsumen. Salah satu upaya untuk mewujudkan hal di atas dengan menerapkan Total Quality Management (TQM). Pada dasarnya, TQM adalah perpaduan semua fungsi dari perusahaan ke dalam falsafah perusahaan yang dibangun berdasarkan konsep kualitas, teamwork, produktivitas dan kepuasan pelanggan.

Seperti diuraikan oleh Fandy Tjiptono dan Anastasia Diana (2000:4), TQM diartikan sebagai berikut: Total Quality Management merupakan suatu pendekatan dalam menjalankan usaha yang mencoba untuk memaksimumkan daya saing organisasi melalui perbaikan terus menerus atas produk, jasa, manusia, proses dan lingkungannya. Berdasarkan pengertian tersebut bahwa TQM adalah sistem manajemen yang mengangkat isu kualitas sebagai upaya untuk memenangkan persaingan dan kinerja yang tinggi dengan perbaikan secara terus menerus.

Selanjutnya, menurut Fandy Tjiptono dan Anastasia Diana (2000:14), terdapat 4 prinsip utama dalam TQM yaitu sebagai berikut: (1) Kepuasan Pelanggan (customer satisfaction), dalam TQM, konsep mengenai kualitas dan pelanggan diperluas. Kualitas tidak lagi hanya bermakna kesesuaian dengan spesifikasi-spesifikasi tertentu, tetapi kualitas tersebut ditentukan oleh pelanggan. Pelanggan itu sendiri meliputi pelanggan internal dan eksternal. Kebutuhan pelanggan diusahakan untuk dipuaskan dalam segala aspek, termasuk di dalam harga, keamanan dan ketepatan waktu. Oleh karena itu segala aktivitas perusahaan harus dikoordinasikan untuk memuaskan para pelanggan; (2) Perbaikan berkesinambungan (Continouos Improvement), agar dapat sukses, setiap perusahaan perlu melakukan proses secara sistematis dalam melaksanakan perbaikan berkesinambungan. Konsep yang berlaku di sini adalah siklus PDCA (plan-do-check-act), yang terdiri dari langkah-langkah perencanaan, pelaksanaan rencana, pemeriksaan hasil pelaksanaan rencana dan tindakan korektif terhadap hasil yang diperoleh; (3) Respek Terhadap Setiap Orang (memberdayakan karyawan), dalam perusahaan yang kualitasnya kelas dunia, setiap karyawan dipandang sebagai individu yang memiliki talenta dan kreativitas tersendiri yang unik. Dengan demikian karyawan merupakan sumber daya organisasi yang paling bernilai. Oleh karena itu setiap orang dalam organisasi diperlakukan dengan baik dan diberi untuk terlibat dan berpartisipasi dalam tim pengambil keputusanl (4) Manajemen Berdasarkan Fakta, perusahaan dalam melaksanakan kegiatannya selalu berorientasi berdasarkan fakta. Maksudnya bahwa setiap keputusan selalu didasarkan pada data, bukan sekedar perasaan. Ada dua konsep pokok berkaitan dengan hal: Pertama, prioritas yakni suatu konsep bahwa perbaikan tidak dilakukan pada semua aspek pada saat yang bersamaan, mengingat keterbatasan sumber daya yang ada. Oleh karena itu, dengan menggunakan data maka manajemen dan tim dalam organisasi dapat memfokuskan usahanya pada situasi tertentu yang vital. Kedua, variabilitas kinerja manusia. Data statistik dapat memberikan gambaran mengenai variabilitas yang merupakan bagian yang wajar dari setiap sistem organisasi. Dengan demikian manajemen dapat memprediksi hasil dari setiap keputusan dan tindakan yang dilakukan.

Untuk memberikan pemahaman yang lebih berkaitan dengan unsur-unsur TQM, lebih lanjut Fandy Tjiptono dan Anastasia Diana (2000:4) menjelaskan sepuluh unsurunsur TQM yaitu: (1) Fokus pada pelanggan; (2) Obsesi terhadap kualitas; (3) Pendekatan ilmiah; (4) Komitmen jangka panjang; (5) Kerjasama tim; (6) Perbaikan 
sistem secara berkelanjutan; (7) Pendidikan dan pelatihan; (8) Kebebasan yang terkendali; (9) Kesatuan tujuan; (10) Adanya keterlibatan dan pemberdayaan karyawan.

Banyak artikel yang sudah mencoba membahas pengertian TQM, namun belum ada kesepakatan tentang definisi dan komponen TQM secara universal dalam literatur manajemen. Masing-masing penulis mempunyai kerangka sendiri dalam merumuskan definisi TQM. Sementara menurut Tenner dan Detoro (1993:32), untuk mengatasi perbedaan berkaitan dengan pengertian TQM, TQM memiliki tiga falsafah dasar yang dapat ditarik sebagai titik pertemuan dari berbagai pendapat tentang TQM yang kemudian dipakai dalam subvariabel penelitian ini. Tiga falsafah dasar yang dimaksud adalah sebagai berikut:

\section{Berfokus pada kepuasan pelanggan (Customer Focus)}

Desain produk dan jasa didasarkan pada upaya untuk memenuhi kebutuhan konsumen. Falsafah yang mendasari prinsip ini adalah adanya keyakinan bahwa kepuasan konsumen merupakan prasyarat penting bagi kesuksesan organisasi dalam jangka panjang.

Pelanggan internal adalah pekerja berikut atau departemen berikut yang terlibat dalam proses produksi/penciptaan jasa. Pelanggan eksternal adalah orang atau organisasi yang membeli dan menggunakan produk atau jasa perusahaan. Secara skematis Schermerborn Jr (1993:692) menggambarkan pelanggan dalam konteks TQM dalam gambar 2:

Tenner dan Detoro (1993:32) mengungkapkan bahwa yang dimaksud dengan fokus kepada pelanggan adalah:"Quality is based on the consept that veryone has a customer and that the requirements, needs and expectation of that customer must be meet every time if the organization as a whole is going to meet the needs of the external customer"

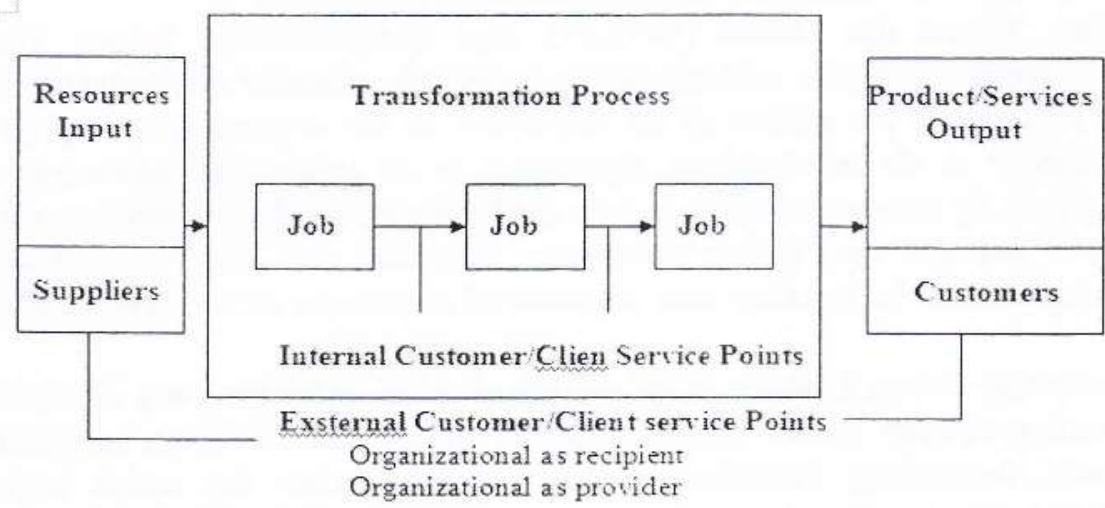

Sumber: Schermerborn Jr (1993:692)

\section{Gambar 2}

\section{Pelanggan Internal dan Eksternal Dalam Aliran Kerja Organisasi}

Lebih lanjut Tenner dan Detoro (1993:51-93) dalam Gunarianto (2005:45) mengungkapkan bahwa pembentukan fokus pada pelanggan meliputi tiga aktivitas utama, yaitu: (a) Mengidentifikasikan pelanggan, meliputi tiga aktivitas utama, yaitu: (1) Mengetahui siapa pelanggan itu, (2) Mengetahui apa yang diinginkan pelanggan,(3) Usaha apa untuk memuaskan pelanggan; (b) Mengerti atau memenuhi harapan-harapan pelanggan (understanding customer expectation), menyangkut: (1) Karakteristik produk/jasa apa yang diinginkan pelanggan, (2) Tingkat kinerja yang dibutuhkan untuk memuaskan harapan-harapan pelanggan, (3)Kepentingan relatif dari masing-masing 
kerakteristik atau pemilihan kepentingan,(4) Bagaimana kepuasan pelanggan, apakah sejalan dengan tingkat kinerja; (c) Tersedianya mekanisme untuk mendengar suara pelanggan (explains how tolisten to the voice of the customer trough an array of readily available mechanisms atau disingkat mechanisms for understanding customer). Ada dua dimensi dari mekanisme untuk mengerti pelanggan, yaitu dimensi pertama, melalui pendekatan supplier atau pemasok. Dimensi kedua, adalah melalui pendekatan pelanggan. Dari kedua dimensi tersebut pada akhirnya akan diketahui jenis dan tipe pemasok dan tipe-tipe pelanggan

\section{Pemberdayaan dan pelibatan karyawan (Employee empowerment and Invoivement)}

Dalam persaingan yang ketat, karyawan dituntut untuk memiliki keahlian dan pengetahuan yang tinggi dalam melaksanakan tugasnya. Keahlian tugas harus diperluas, tidak hanya untuk menyelesaikan tugas-tugas utama (basic work task), namun juga meliputi keahlian menyelesaikan masalah (problem solving skill) guna mengubah cara pandang perusahaan dalam menjalankan aktivitasnya. Oleh karena itu perusahaan harus lebih banyak menyediakan pelatihan dan kesempatan untuk terlibat dalam proses pengambilan keputusan. Untuk itu pelatihan yang dilakukan bersifat dinamis dengan waktu yang fleksibel dan mampu menggugah kreasi karyawan.

Menurut Tenner dan Detoro (1993:179-182), terlepas tiga dimensi dalam membangun pemberdayaan karyawan ini, yaitu: (a) Membangun kesejajaran (alignment), melalui: (1) Memberi pengajaran tentang misi, visi, nilai dan tujuan/sasaran, (2) Membangun komitmen pada setiap orang; (b) Membangun kekampuan (capability) dengan sasaran pada: (1) Individu: kecakapan (ability), keterampilan (skill) dan pengetahuan (knowledge), (2) Sistem: kemampuan dalam menangani bahan baku (materials), metode (methods) dan mesin (machines); (3) Membangun kepercayaan (trust), bisa dicapai dengan cara saling mempercayai antara para manajer dan para karyawan (the can trust their managers, and their manager trust them)

Kemudian, Tenner dan Detoro (1993:33), juga mengemukakan bahwa: Total involvement: This approach begins with the active leadership of senior management and includes efforts that utilize the talents of all employees in the organization to gain a competitive advantage in the marketplace. Employees at all levels are empowered to improve their outputs by coming together in new and fleksible work structures to solve problems, improve process, and satisfy customers. Suppliers are also included and, overtime, become partners be working with empowered employees to the benefit of the organization.

Kepemimpinan dalam konteks TQM adalah aktivitas-aktivitas yang dilakukan para manajer senior dengan penuh tanggung jawab untuk mensukseskan organisasi berdasarkan posisi, wewenang, kebijakan, alokasi sumber-sumber dan ambil bagian seleksi pasar. Para manajer juga harus bertanggung jawab terhadap para pelanggan, karyawan dan para pemegang saham untuk mensukseskan organisasinya. Dengan kata lain TQM memerlukan dua keterampilan yaitu keterampilan memimpin dan keterampilan untuk mengelola (kepemimpinan dan manajerial)

\section{Peningkatan kualitas secara berkelanjutan (continuous improvement)}

Keseimbangan perbaikan kualitas menuntut adanya komitmen untuk melakukan pengujian kualitas secara berkelanjutan (dalam metode penelitian yang lebih baik), baik dalam proses administratif maupun proses teknikal. Falsafah yang mendasari prinsip ini adalah adanya konsep bahwa organisasi merupakan proses yang saling terkait, dan adanya keyakinan bahwa dengan memperbaiki proses ini organisasi dapat memenuhi harapan konsumen yang terus meningkat. 
Tenner dan Detoro (1993:32) mengungkapkan bahwa: "the consept or continuous improvment is built on the premise that work is the result of a series of interelated steps and activities that result in an output".

Dalam implementasinya perbaikan proses tersebut dijalankan berdasarkan roda Deming yaitu plan, do, check dan action (siklus PDCA) yang memutar rodanya terus menerus untuk mencegah terulangnya kerusakan. Siklus tersebut dijabarkan ke dalam enam kegiatan yang saling berkaitan satu sama lainnya (Tenner dan Detoro, 1993:110121), yaitu: (1) Menetapkan masalah (define problem), aktivitasnya meliputi: (a) Mengidentifikasi produk atau jasa yang dihasilkan, (b) Mengidentifikasi pelanggan, (c) Mengidentifikasi persyaratan-persyaratan yang diinginkan pelanggan; Mengidentifikasikan dan proses dokumentasi (identify and document process), meliputi: (a) Mengidentifikasi semua personil atau karyawan, (b) Pengarahan kepada semua karyawan untuk memahami perannya dalam melakukan semua tugas-tugasnya., (c) Mengidentifikasi pemborosan dalam proses produksi; (3) Mengukur kinerja (measure performance), hal ini bisa dilakukan melalui: (a) Mengukur kepuasan pelanggan, (b) menilai persyaratan-persyaratan yang diinginkan pelanggan; (4) Mengerti tentang berbagai masalah/mengapa (understanding/ why), yaitu dengan cara membedakan kasuskasus biasa, kasus-kasus khusus, dan kemampuan untuk menganalisis; (5) mengembangkan dan tes ide-ide (develop and test ideas), tahap ini bisa dilakukan melalui: (a) Mengembangkan ide-ide baru, (b) Percobaan-percobaan, (c) Menguji ide-ide untuk menyelesaikan kasus-kasu pokok; (6) Evaluasi dan implementasi pemechan masalah (implement solution and evaluate), meliputi: (a) Mengevaluasi kinerja/hasil yang telah dicapai, (b) Mengevaluasi semua tahap proses perbaikan di atas, (c) Penghargaan terhadap para karyawan atas prestasi-prestasinya, (d) Kembali ke tahap awal.

Dalam menjalankan aktivitas-aktivitas di atas, maka untuk keberhasilan suatu program continuous improvement diperlukan alat untuk menganalisisnya. Alat yang dimaksud adalah yang dikembangkan untuk penerapan teknik-teknik manajemen mutu.

Walaupun tiga prinsip dasar tersebut di atas dapat dibedakan, masing-masing saling terkait dalam mewujudkan kekuatan TQM. Ketiga prinsip ini dapat diimplementasikan melalui serangkaian strategi, praktik dan teknik tertentu. Dua tahapan strategi untuk menerapkan TQM adalah sebagai berikut (Soewarso.2002:10): (a) Perencanaan dan pelaksanaan upaya perbaikan awal serta menyediakan sumber daya yang diperlukan untuk mendukung pelaksanaan TQM. Isu yang penting dalam tahap ini adalah penjadwalan dan pelaksanaan program pendidikan dan pelatihan; (b) Pelaksanaan perbaikan kualitas secara berkelanjutan dengan mengadakan modifikasi pada sistem budaya, sistem teknis dan struktur kewenangan dalam organisasi.

Wilkinson (1992:64-68) berpendapat bahwa penerapan TQM dapat dilihat dari dua sisi. Pendapat ini didasarkan pada definisi TQM sebagai konsep yang mempunyai dua sisi kualitas. Sisi pertama disebut sebagai "hard side of quality", meliputi semua upaya perbaikan proses produksi, mulai dari desain sampai dengan penggunaan alat-alat pengendalian seperti: quality function deployment, just in time dan ststistical process control. Apabila sebuah perusahan sudah melakukan upaya perbaikan kualitas ini atau sudah menggunakan alat-alat pengendalian kualitas, maka dapat dikatakan bahwa perusahaan tersebut sudah menerapkan TQM pada sisi "hard side of quality". Dengan upaya demikian, diharapkan akan dapat meningkatkan kualitas produk yang pada akhirnya dapat memuaskan kebutuhan konsumen.

Sisi kedua disebut sebagai "soft side of quality" yang lebih memfokuskan pada upaya menciptakan keasadaran karyawan akan pentingnya arti kepuasan konsumen serta menimbulkan komitmen karyawan untuk selalu memperbaiki kualitas. Perusahaan dapat melakukan upaya tersebut melalui pendidikan, pelatihan, pendekatan sistem pengupahan, 
promosi dan struktur kerja yang mendukung dan sebagainya. Dengan upaya demikian diharapkan akan dapat meningkatkan kepuasan kerja karyawan. Karyawan yang memperoleh kepuasan kerja yang tinggi pada gilirannya diharapkan dapat mendukung dan mempunyai komitmen yang tinggi pada giliannya diharapkan dapat mendukung dan mempunyai komitmen yang tinggi terhadap pencapaian tujuan organisasi, yaitu memuaskan kebutuhan konsumen dalam jangka panjang.

Selanjutnya, implementasi total quality management pada lembaga amil zakat (LAZ), dimana dalam rangka mewujudkan lembaga zakat yang kredibel, salah satu upaya yang harus dilakukan adalah dengan menerapkan Total Quality Management (TQM). Dalam penerapan TQM, pelanggan harus didefinisikan secara jelas (Mulyadi:1996:10) yaitu yang dimaksud dengan pelanggan adalah muzakki dan mustahiq. Dengan demikian nilai pelanggan adalah terpenuhinya niat muzakki untuk melaksanakan pembayaran Zakat, Infak dan Shadaqoh (dana ZIS) dan terangkatnya kehidupan, derajat dan martabat mustahiq.

Lebih lanjut, khususnya LAZ, menurut (Budi:2002:16) upaya melakukan perbaikan kualitas secara terus menerus dapat dicapai dengan dua cara yaitu sebagai berikut: (1) LAZ dapat membuat suatu posisi yang lebih strategis dalam hal pengelolaan ZIS dengan cara mensosialisasikan tentang konsepsi fiqh yang lebih sesuai, pada cara ini, LAZNAS perlu membuat jaringan kerja sama dengan unsur atau komponen masyarakat dan membuat diversifiaksi konsepsi fiqh zakat yang dapat meningkatkan pelayanan baik secara kuantitas maupun kualitas kepada masyarakat; (2) LAZ dapat meningkatkan hasil yang terbebas dari kerusakan dalam arti yang dapat menghambat operasional lembaga, cara ini dapat berdampak pada pengurangan biaya operasional, terciptanya manajemen yang terbuka dan transparan serta terwujudnya suatu optimalisasi semua potensi yang ada dalam masyarakat seperti ulama, cendekiawan dan profesional.

Diharapkan dengan perbaikan kualitas secara terus menerus dengan dua cara di atas maka LAZNAS diharapkan dapat mencapai tujuannya yaitu dapat meningkatkan dana zakat, infak dan shadaqoh dari muzakki dan mampu mendistribusikan dana zakat, infak dan shadaqoh kepada mustahik, serta mampu meningkatkan pelayanan kepada masyarakat secara optimal dan akhirnya dapat meningkatkan partisipasi masyakarat kepada keberhasilan lembaga juga meningkatkan daya saing lembaga dalam bentuk kinerja yang tinggi.

Upaya memperbaiki posisi bisa dilakukan dengan memperbaiki jaringan yang banyak atau membuat kantor cabang dan membuat diversifikasi konsepsi fiqh zakat. Kedua upaya untuk memperbaiki posisi tersebut memiliki tujuan akhir meningkatkan penghimpunan dana zakat, infak dan shadaqoh. Di sisi lain untuk meningkatkan output yang terbebas dari kerusakan bisa dilakukan dengan berbagai cara seperti: mengurangi biaya operasional, mengimplementasikan manajemen yang terbuka dan transparan dan melakukan optimalisasi terhadap potensi-potensi yang ada di dalam masyarakat. Upayaupaya tersebut pada akhirnya dapat meningkatkan pelayanan kepada masyarakat yang pada akhirnya akan memunculkan partisipasi masyarakat yang besar pula.

\section{Metode Penelitian}

Metode penelitian yang direncanakan dalam penelitian ini adalah penelitian yang bersifat analisis kualitatif deskriptif dengan wawancara secara mendalam (depth interview) Selanjutnya, untuk memperoleh data yang dibutuhkan untuk menjawab identifikasi penelitian, teknik pengumpulan data yang digunakan, yaitu Observasi, Kuesioner, Wawancara dan Dokumentasi. Selanjutnya dilakukan pengujian validitas dan reliabilitas instrumen penelitian ini. 
Target populasi dalam penelitian ini adalah Lembaga Amil Zakat yang terdaftar di Forum Zakat sebagai anggota aktif yang terdiri dari LAZNAS dan LAZDA yang terdaftar pada FoZ sebagai anggota aktif. Teknik penentuan sampel adalah Proportional Stratified Random Sample. Adapun penentuan sampel menggunakan rumus Slovin, dengan tingkat kekeliruan (d) sebesar 0,05 :

Tabel 3

Banyaknya Unit Sampel dari Setiap Strata LAZ

\begin{tabular}{|c|c|c|}
\hline Lembaga Amil Zakat (LAZ) & N & n \\
\hline LAZ Nasional (LAZNAS) & 18 & 16 \\
\hline LAZ Daerah (LAZDA) & 32 & 28 \\
\hline Total & $\mathbf{5 0}$ & $\mathbf{4 4}$ \\
\hline
\end{tabular}

Sumber: Data yang diolah kembali

Dari jumlah target populasi yang berjumlah $50 \mathrm{LAZ}$, yang mengisi kuesioner dalam penelitian ini berjumlah 41 LAZ, terdiri dari 14 LAZNAS dan 27 LAZDA, sedangkan $9 \mathrm{LAZ}$ tidak bersedia dijadikan sebagai target populasi/responden penelitian.

Sesuai dengan perumusan masalah, tujuan penelitian, dan jumlah data yang akan dikumpulkan maka metode analisis data yang digunakan dalam penelitian ini adalah menggunakan analisis kualitatif deskriptif dengan wawancara mendalam (depth interview) tentang bagaimana implementasi pengendalian intern pada Lembaga Amil Zakat (LAZ) seluruh Indonesia.

\section{Hasil Penelitian dan Pembahasan}

Penelitian ini untuk mengetahui dan menganalisis implementasi pengendalian intern pada Lembaga Amil Zakat (LAZ) seluruh Indonesia.

Analisis dilakukan dengan cara mengumpulkan data empiris dengan mengambil unit analisis LAZ seluruh Indonesia dengan target populasi LAZ sebagai anggota Forum Zakat yang aktif dengan jumlah $50 \mathrm{LAZ}$. Adapun jumlah responden penelitian ini ádalah 50 direktur utama atau pimpinan LAZ. Berkaitan dengan penyebaran kuesioner, agar terpenuhi sesuai dengan jumlah sampel penelitian, peneliti menyebarkan kuesioner sebanyak jumlah target populasi. Dari jumlah target populasi yang berjumlah $50 \mathrm{LAZ}$, yang mengisi kuesioner dalam penelitian ini berjumlah 41 LAZ dari 34 yang ditargetkan, terdiri dari 14 LAZNAS dan 27 LAZDA, sedangkan 9 LAZ tidak bersedia dijadikan sebagai responden penelitian. Selanjutnya, untuk memperoleh representasi yang lebih baik, maka seluruh kuesioner yang kembali diolah sebagai data penelitian. Di bawah ini disajikan LAZ yang bersedia dijadikan target populasi sebagai berikut:

Tabel 4.1

Daftar LAZ Yang Bersedia Menjadi Target Populasi Penelitian

\begin{tabular}{|c|l|c|c|}
\hline No & \multicolumn{1}{|c|}{ Lembaga Amil Zakat } & Kota & Basis \\
\hline 1 & LAZ Dompet Peduli Ummat-Daarut Tauhid & Bandung & Masjid \\
\hline 2 & LAZ Al Azhar Peduli Ummat & Bandung & Masjid \\
\hline 3 & LAZ Masjid Agung Semarang & Semarang & Masjid \\
\hline 4 & LAZ Rumah Amal Salman ITB Bandung & Bandung & Masjid \\
\hline 5 & LAZ Baitul Maal Sunda Kelapa & Jakarta & Masjid \\
\hline 6 & LAZ LAZIS Muhammadiyah & Jakarta & Ormas \\
\hline 7 & LAZ Pusat Zakat Ummat (LAZ PZU) & Bandung & Ormas \\
\hline 8 & LAZ Nahdlatul Ulama (NU) & Jakarta & Ormas \\
\hline 9 & $\begin{array}{l}\text { LAZ Yayasan Baitul Maal Ummat Islam PT BNI } \\
\text { (persero) tbk }\end{array}$ & Jakarta & Perusahaan \\
\hline 10 & LAZ Yayasan Baitul Maal Bank Rakyat Indonesia & Jakarta & Perusahaan \\
\hline 11 & LAZ Baitul Maal Muttaqien Telkom & Bandung & Perusahaan \\
\hline
\end{tabular}




\begin{tabular}{|c|l|c|c|}
\hline No & \multicolumn{1}{|c|}{ Lembaga Amil Zakat } & Kota & Basis \\
\hline 12 & LAZ Baitul Maal Pupuk Kujang & Cikampek & Perusahaan \\
\hline 13 & LAZ LAZIS Garuda & Jakarta & Perusahaan \\
\hline 14 & LAZ Baituzzakah Pertamina (BAZMA) & Jakarta & Perusahaan \\
\hline 15 & LAZ Baitul Maal Pupuk Kaltim (BMPKT) & Bontang & Perusahaan \\
\hline 16 & LAZ Yayasan Baitul Maal Muammalat & Jakarta & Perusahaan \\
\hline 17 & LAZ Bina Sejahtera Mitra Ummat (BSM Umat) & Jakarta & Perusahaan \\
\hline 18 & LAZ Yayasan Amanah Takaful & Jakarta & Perusahaan \\
\hline 19 & LAZ BPZIS Bank Mandiri & Jakarta & Perusahaan \\
\hline 20 & LAZ Dompet Dhuafa (LAZ DD) & Jakarta & OPZ \\
\hline 21 & LAZ Pos Keadilan Peduli Ummat (PKPU) & Jakarta & OPZ \\
\hline 22 & LAZ LAZIS Peduli (LAZIS Malang) & Malang & OPZ \\
\hline 23 & LAZ Lembaga Manajemen Infaq (LMI) & Jakarta & OPZ \\
\hline 24 & LAZ Portal Infaq & Jakarta & OPZ \\
\hline 25 & LAZ Nasional Yakarta (Baznas) & Jakarta & OPZ \\
\hline 26 & LAZ Rumah Sosial Insan Madani & Samarinda & OPZ \\
\hline 27 & LAZ LAZIS Surabaya & Surabaya & OPZ \\
\hline 28 & LAZ LP-UQ Jombang & Jombang & OPZ \\
\hline 29 & LAZ LAZIS DKI Jakarta & Jakarta & OPZ \\
\hline 30 & LAZ Dompet Amal Sejahtera Ibnu Abbas Mataram & Mataram & OPZ \\
\hline & LAZ DASI) & & \\
\hline 31 & LAZ DSM Bali & Denpasar & OPZ \\
\hline 32 & LAZ Yayasan Dana Sosial Al-Falah (LAZ YDSF) & Surabaya & OPZ \\
\hline 33 & LAZ Rumah Zakat Indonesia (RZI) & Bandung & OPZ \\
\hline 34 & LAZ Lembaga Kemanusiaan Amany Percikan Iman & Bandung & OPZ \\
\hline 35 & Bandung & & \\
\hline 36 & LAZ Pondok Zakat Jambi & Jambi & OPZ \\
\hline 37 & LAZ Rumah Yeduli Umat Waspada Medan & Medan & OPZ \\
\hline 38 & LAZ LAZIS Jakarta & Bandung & OPZ \\
\hline 39 & LAZ Solo Peduli & Jakarta & OPZ \\
\hline 40 & LAZ Lampung Peduli & Solo & OPZ \\
\hline 41 & LAZ Makasar & Lampung & OPZ \\
\hline Manar & Makasar & OPZ \\
\hline
\end{tabular}

Sumber: Forum Zakat (2010) dan data penelitian diolah kembali

\section{Deskripsi Lembaga Amil Zakat}

Dilihat dari sejarah pendirian LAZ yang menjadi target populasi penelitian ini, terbagi menjadi empat kelompok bedasarkan alasan dan sejarah pendirian, yaitu: (a) LAZ yang berbasis masjid, LAZ didirikan dengan basis masjid seperti: LAZ Rumah Amal Salman (masjid Salman ITB); LAZ Al Azhar Peduli (masjid Al Azhar); dan LAZ DPUDT (masjid Daarut Tauhid). Umumnya, pendirian LAZ ini sebagai akibat dari perkembangan yang pesat dalam manajemen masjid dan kepercayaan masyarakat (jamaah masjid), khususnya berkaitan dengan pengelolaan keuangan masjid (termasuk dana ZIS oleh DKM masjid). Selanjutnya adanya dana yang besar harus dikelola lebih profesional melalui pendirian LAZ sebagai bentuk tangung jawab pengelola dan untuk meningkatkan peran masjid kepada masyarakat, baik masyarakat sekitar masjid maupun masyarakat luas; (b) LAZ yang berbasis Organisasi Massa (Ormas), LAZ pada kelompok ini, didirikan dengan basis organisasi masa (ormas) seperti LAZ Pusat Zakat Ummat (Ormas Persis), LAZ NU (Ormas NU), dan LAZ Muhammadiyah (Ormas Muhammadiyah). 
Umumnya, LAZ didirikan dalam rangka dan menjadi media untuk meningkatkan peran organisasi masa bagi masyarakat, baik masyarakat anggota organisasi masa tersebut maupun masyarakat luas; (c) LAZ berbasis Perusahaan (Corporate), LAZ didirikan dengan basis perusahaan (corporate) seperti: LAZ Baitul Maal Muttaqien (PT. Telkom); Baitul Maal Muammalat (Bank Muammalat Indonesia); Baitul Maal BRI (Bank BRI); Baitul Maal Pupuk Kujang (PT. Pupuk Kijang Cikampek). Umumnya pendirian LAZ ini, sebagai bagian dari program pertanggungjawaban sosial perusahaan (CSR). Selanjutnya untuk mengelola dana CSR perusahaan yang besar, perlu lembaga yang profesional, diantaranya dengan mendirikan LAZ. Kemudian, diharapkan dengan pendirian LAZ, program-program CSR perusahaan akan lebih terarah, bersifat sistematis dan berdampak jangka panjang, juga meningkatkan peran perusahaan bagi masyarakat khususnya bidang sosial kemasyarakatan; (d) LAZ berbasis sebagai Organisasi Pengumpul Zakat (OPZ), LAZ didirikan dengan tujuan awal sebagai organisasi pengelola zakat (OPZ). LAZ dalam kelompok ini seperti: LAZ Rumah Zakat Indonesia; LAZ Dompet Dhuafa; LAZ Rumah Yatim Arrohman. Alasan pendirian LAZ ini, sebagai bentuk partisipasi masyarakat (civil society) berkaitan dengan pengelolaan dana ZIS yang lebih profesional.

Pembagian berdasarkan alasan atau sejarah pendirian LAZ akan menentukan pola pengelolaan dana zakat, sebagai berikut:

\section{Tabel 4.2}

Deskripsi Lembaga Amil Zakat Berdasarkan Alasan Pendiriannya

\begin{tabular}{|c|c|c|c|c|}
\hline & $\begin{array}{c}\text { Berbasis } \\
\text { Masjid }\end{array}$ & Berbasis Ormas & $\begin{array}{c}\text { Berbasis } \\
\text { Perusahaan }\end{array}$ & Berbasis OPZ \\
\hline $\begin{array}{l}\text { Pola } \\
\text { Penghimpun } \\
\text { an Zakat }\end{array}$ & $\begin{array}{l}\text { - Muzaki } \\
\text { utama } \\
\text { berasal dari } \\
\text { jamaah } \\
\text { masjid } \\
\text { - Masyarakat } \\
\text { luas }\end{array}$ & $\begin{array}{l}\text { - Muzaki utama } \\
\text { berasal dari } \\
\text { anggota ormas } \\
\text { - Masyarakat } \\
\text { Luas }\end{array}$ & $\begin{array}{l}\text { - Muzaki utama } \\
\text { berasal dari } \\
\text { zakat karyawan/ } \\
\text { pegawai/ } \\
\text { manajemen } \\
\text { - Masyarakat luas }\end{array}$ & $\begin{array}{l}\text { Muzaki utama } \\
\text { berasal dari } \\
\text { masayarakat luas }\end{array}$ \\
\hline $\begin{array}{l}\text { Pola } \\
\text { Pemberdaya } \\
\text { an Zakat }\end{array}$ & $\begin{array}{l}\text { - Diperuntukk } \\
\text { an bagi } \\
\text { jamaah } \\
\text { masjid } \\
\text { - Masyarakat } \\
\text { luas } \\
\end{array}$ & $\begin{array}{l}\text {-Diperuntukkan } \\
\text { bagi anggota } \\
\text { ormas } \\
\text { - Masyarakat } \\
\text { Luas }\end{array}$ & $\begin{array}{l}\text { - Diperuntukkan } \\
\text { bagi karyawan } \\
\text { yang } \\
\text { membutuhkan } \\
\text { - Masyarakat luas }\end{array}$ & $\begin{array}{l}\text { Diperuntukan } \\
\text { bagi mustahik } \\
\text { yang berasal dari } \\
\text { masyarakat luas }\end{array}$ \\
\hline $\begin{array}{l}\text { Pola Relasi } \\
\text { Konsumen }\end{array}$ & $\begin{array}{l}\text { Diselearaskan } \\
\text { dengan } \\
\text { program yang } \\
\text { sudah dibuat } \\
\text { oleh DKM } \\
\text { Masjid, } \\
\text { penyampaian } \\
\text { informasi } \\
\text { dengan media } \\
\text { cetak, } \\
\text { elektronik, dll }\end{array}$ & $\begin{array}{l}\text { Diselaraskan } \\
\text { dengan program } \\
\text { ormas seperti } \\
\text { baksos, pengajian, } \\
\text { penyampaian } \\
\text { informasi dengan } \\
\text { media cetak, } \\
\text { elektronik, dll }\end{array}$ & $\begin{array}{l}\text { Diselaraskan dengan } \\
\text { kebijakan perusahaan } \\
\text { seperti aturan yang } \\
\text { diberlakukan bagi } \\
\text { semua karyawan, } \\
\text { penyampaian } \\
\text { informasi dengan } \\
\text { media cetak, } \\
\text { elektronik, dll }\end{array}$ & $\begin{array}{l}\text { - Kegiatan dibuat } \\
\text { sesuai dengan } \\
\text { kebutuhan/ } \\
\text { permintaan } \\
\text { muzaki } \\
\text { - Penyampian } \\
\text { informasi } \\
\text { melalui } \\
\text { berbagai media } \\
\text { yang bisa } \\
\text { diakses } \\
\text { masyarakat luas }\end{array}$ \\
\hline $\begin{array}{l}\text { Pola } \\
\text { Penciptaan } \\
\text { Program }\end{array}$ & $\begin{array}{l}\text { - Dipadukan } \\
\text { dengan } \\
\text { program }\end{array}$ & $\begin{array}{l}\text { Dipadukan dengan } \\
\text { program } \\
\text { kemasayarakatan } / \mathrm{s}\end{array}$ & $\begin{array}{l}\text { - Dipadukan } \\
\text { dengan } \\
\text { program CSR }\end{array}$ & $\begin{array}{l}\text { Dirancang sesuai } \\
\text { dengan kebutuhan } \\
\text { muzaki/mustahik }\end{array}$ \\
\hline
\end{tabular}




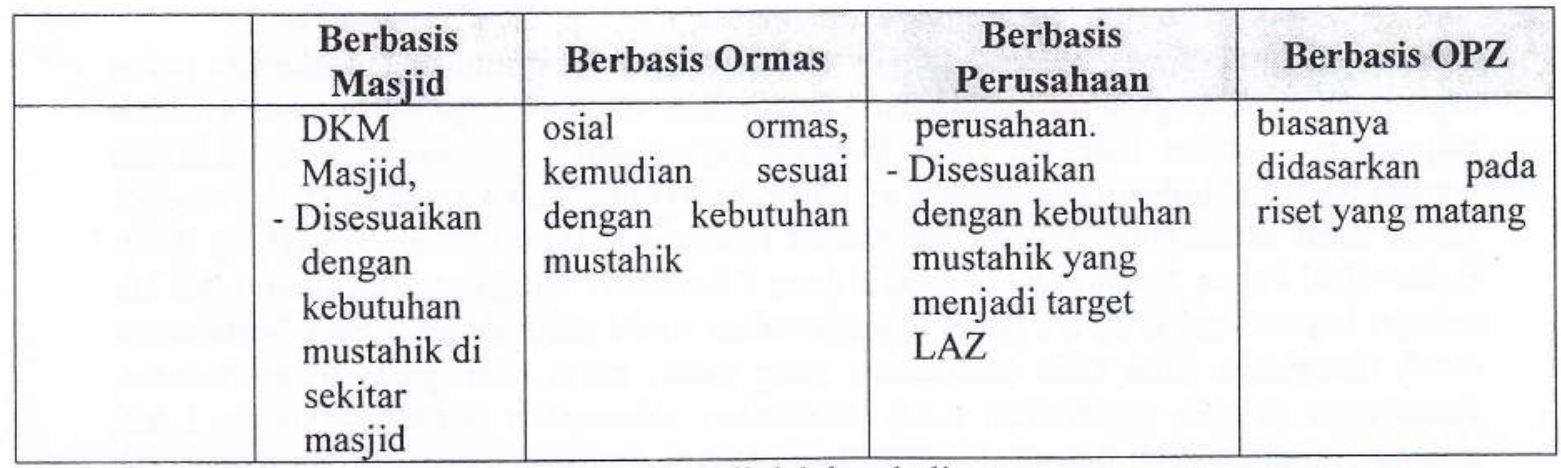

Sumber: Hasil kuesioner dan interview yang diolah kembali

Selanjutnya, untuk melihat pengelolaan zakat yang dilakukan oleh LAZ di Indonesia dapat dilihat dari hal berikut:

\section{Struktur Organisasi Lembaga Amil Zakat}

Pada dasarnya rancang bangun struktur organisasi dan susunan personalia untuk LAZ tidak diatur oleh Kepmen Agama Republik Indonesia, akan tetapi diatur oleh masing-masing LAZ dengan memperhatikan berbagai peraturan yang berlaku. Namun, demikian bentuk struktur organisasi masing-masing LAZ akan tergantung pada perkembangan dan kebutuhan LAZ tersebut. Berdasarkan data riset, terdapat struktur organisasi LAZ, masih sederhana dan yang sangat kompleks. Untuk memberikan gambaran tersebut, di bawah ini disajikan struktur organisasi LAZ Dompet Peduli Ummat Daarut Tauhid dan LAZ Dompet Dhuafa seperti pada gambar 4.1 berikut ini:

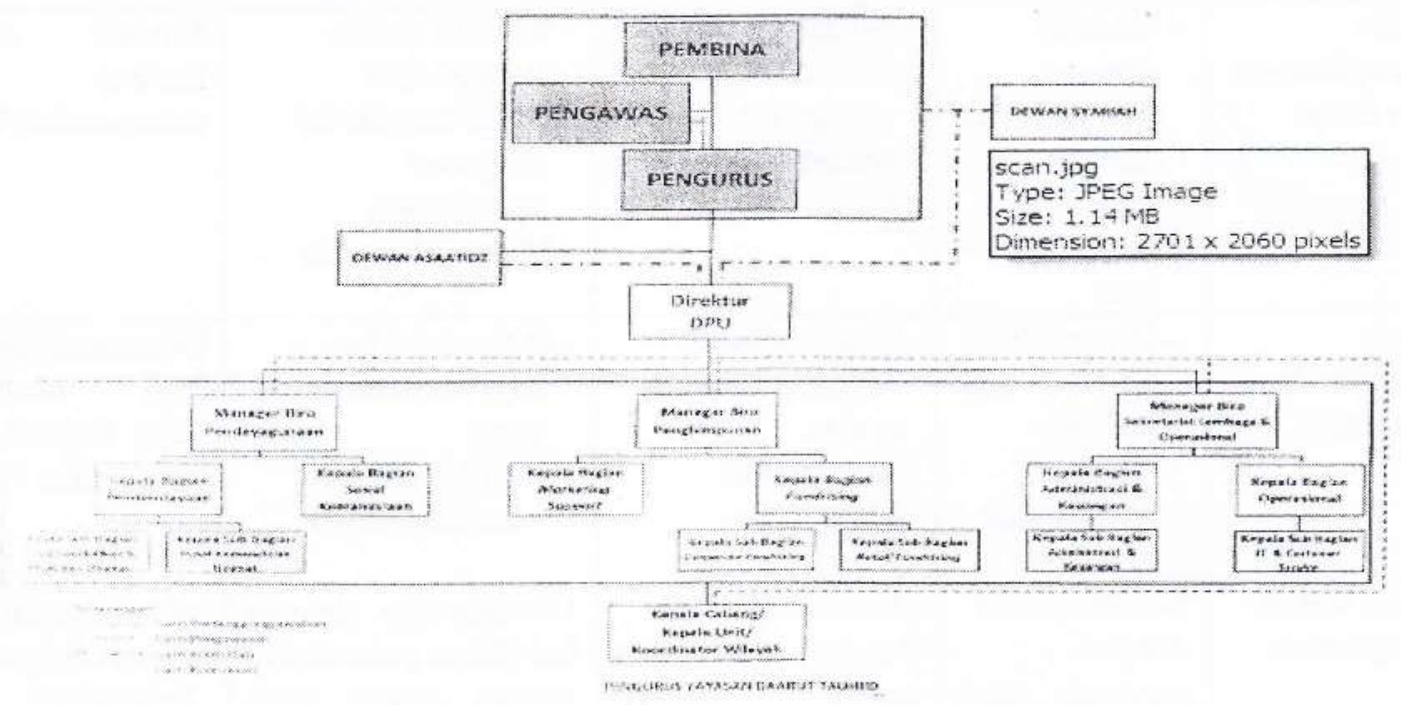

Gambar 4.1

Struktur Organisasi LAZ Dompet Peduli Ummat Daarut Tauhid

Sumber: Dokumentasi LAZ DPU DT (2009)

Pada prinsipnya, bentuk struktur organisasi di atas, menggambarkan bahwa LAZ tidak saja sebagai organisasi pengelola zakat yang bersifat voluntir dan konvensional, tetapi dikelola secara profesional dengan prinsip-prinsip manajemen modern. Hal tersebut tercermin pada struktur organisasi LAZ Dompet Dhuafa, pada gambar 4.2 di bawah ini: 


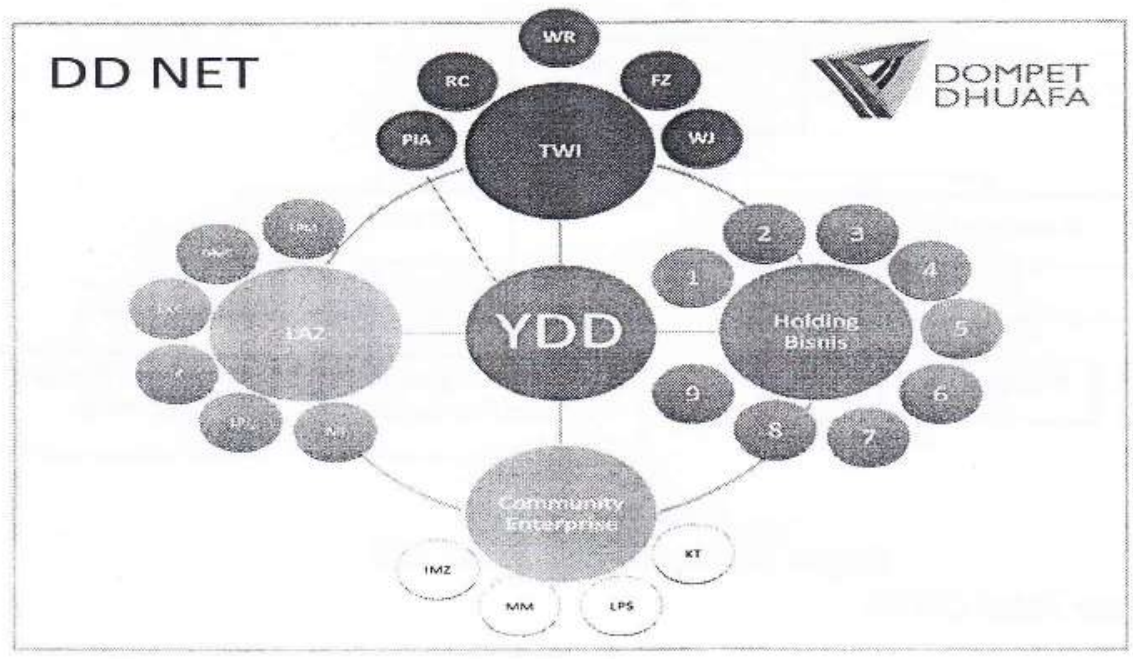

Gambar 4.2

Struktur Organisasi Lembaga Amil Zakat

LAZ Dompet Dhuafa (LAZ DD)

Sumber: Dokumentasi LAZ Dompet Dhuafa (2011)

\section{Penghimpunan Zakat}

Sebagaimana telah dijelaskan sebelumnya, berdasarkan UU Pengelolaan Zakat No. 38/1999, dana zakat dapat dikumpulkan melalui LAZ, sebagai organisasi nonpemerintahan yang tersebar di seluruh pelosok tanah air. Dana yang dikelola oleh LAZ pada umumnya terdiri dari Dana Zakat, Infaq dan Shadaqah (dana ZIS). Namun demikian, terdapat beberapa LAZ yang mengelola dana wakaf seperti LAZ DPU-DT, LAZ Rumah Amal Salman ITB dan LAZ lainnya. Berkaitan dengan jenis dana yang dikelola, Undang-Undang tidak membatasinya, namun dalam operasionalnya diserahkan pada Dewan Syariah masing-masing LAZ, khususnya berkaitan dengan pemberdayaan dana ZIS dan wakaf, supaya tidak bertentangan dengan ketentuan syariahnya.

Secara umum besar kecilnya jumlah penghimpunan dana ZIS dilakukan oleh LAZ akan dipengaruhi oleh: meningkatnya kesejahteraan masyarakat Indonesia, tingginya kesadaran untuk menderma dan membayar zakat pada LAZ, banyaknya jumlah BAZ/LAZ yang gencar mensosialisasikan dan memfasilitasi penyaluran zakat, tingkat kepercayaan masyarakat khususnya muzaki untuk menyalurkan dana zakatnya kepada LAZ semakin meningkat dibanding disalurkan pada BAZ (Dikdik.2010).

\section{Pemberdayaan Zakat}

Undang-Undang nomor 38/1999 secara spesifik menyebutkan bahwa pemberdayaan dana zakat, untuk memenuhi kebutuhan hidup para mustahik. Mustahik terdiri dari delapan asnaf, yaitu: Fakir, Miskin, Amil, Muallaf, Riqab, Gharim, Sabilillah dan Ibnussabil. Berdasarkan amanat UU tersebut, bahwa dana zakat dapat didistribusikan pada dua jenis kegiatan besar, yakin kegiatan konsumtif dan produktif. Kegiatan konsumtif ádalah kegiatan yang berupa bantuan untuk menyelesaikan masalah yang bersifat mendesak dan langsung habis setelah bantuan tersebut digunakan. Sementara kegiatan produktif ádalah kegiatan yang diperuntukkan bagi usaha produktif yang bersifat jangka menengah-panjang. Dampak dari kegiatan produktif ini, umumnya bisa dirasakan walaupun dana ZIS yang diberikan sudah habis terpakai. Lebih jauh, pemberdayaan dana ZIS, seperti makanan, kesehatan dan pendidikan. Apabila kebutuhan tersebut sudah terpenuhi atau terdapat kelebihan, alokasi dapat diperuntukkan bagi kegiatan usaha yang produktif melalui program pemberdayaan yang berkesinambungan. Adapun klasifikasi pemberdayaan dana zakat ini terlihat pada gambar berikut: 


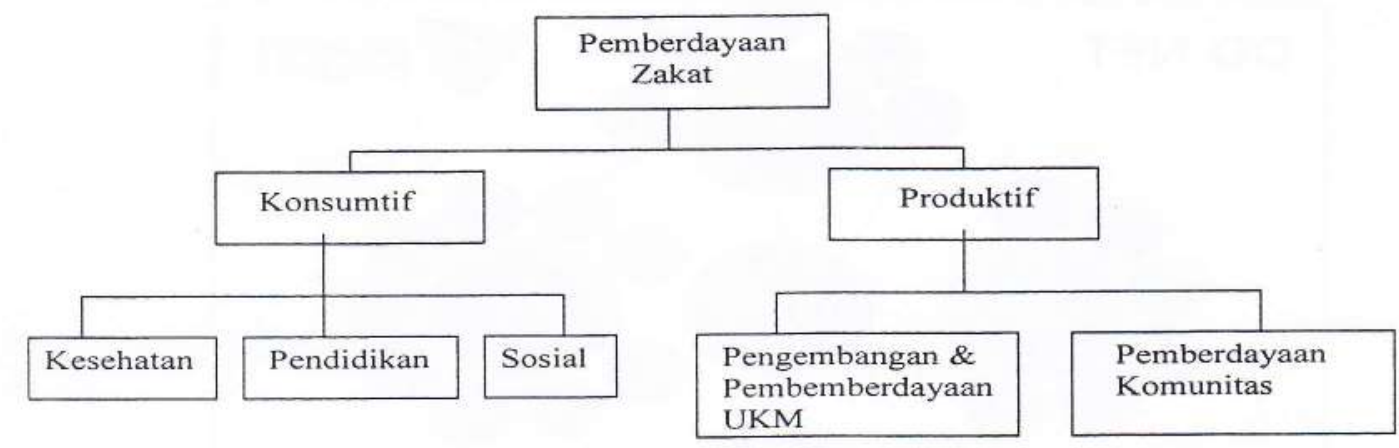

Gambar 4.3

Sumber: Forum Zakat (2010)

\section{Bagan Pemberdayaan Dana ZIS}

\section{Program-Program Yang Ditawarkan LAZ}

Pada prinsipnya, pemberdayaan dana ZIS dilakukan melalui program-program yang ditawarkan LAZ. Secara garis besar, terdapat empat kelompok program yang ditawarkan oleh LAZ, yaitu bidang kesehatan, bidang ekonomi, bidang pendidikan dan program yang bersifat charity. Pada dasarnya, jenis dan banyaknya program yang ditawarkan oleh LAZ akan tergantung pada: (1) besarnya dana yang dikelola LAZ; (2) luas cakupan layanan/target mustahik yang dibidik dan (3) kebutuhan mustahik. Penamaan dari keempat kelompok program tersebut akan berbeda-beda, karena akan disesuaikan dengan peruntukkan, pengistilahan dan aktivitas utama dari LAZ tersebut.

Pemaparan program-program yang ditawarkan beberapa LAZ yang menjadi unit analisis penelitian (tidak semua program LAZ ditampilkan karena keterbatasan ruang, uraian lengkap dalam lampiran). Adapun tujuan pemaparan program-program yang ditawarkan LAZ untuk: (a) Mengetahui bagaimana aktivitas pemberdayaan dana zakat yang dikemas dalam bentuk program-program yang ditawarkan LAZ; (b) Melihat cakupan layanan yang bisa diberikan oleh masing- masing LAZ; (c) Melihat kreativitas dan inovasi berkaitan dengan penciptaaan program-program yang ditawarkan LAZ.

Selanjutnya, di bawah ini akan disajikan contoh program-program yang ditawarkan LAZ, yaitu:

\section{LAZ Rumah Zakat Indonesia (RZI) Bandung}

(a) Senyum Juara merupakan program yang bertujuan mengantarkan anak bangsa untuk mendapatkan masa depan yang lebih baik dengan program-program di bidang pendidikan. Program Senyum Juara terdiri dari: Sekolah Juara (SD-SMP), Laboratorium Juara, Beasiswa Ceria SD-SMA, Mobil Juara, Beasiswa Mahasiswa, Gizi Sang Juara, Beasiswa Juara SD-SMP dan Kemah Juara; (b) Senyum Sehat merupakan program yang menyediakan berbagai pelayanan kesehatan bagi masyarakat kurang mampu yang tidak dapat mengakses kesehatan secara gratis. Program Senyum Sehat terdiri dari: Rumah Bersalin Gratis, Siaga sehat, Layanan bersalin Gratis, Siaga Gizi Balita, Armada Sehat Keluarga, Revitalisasi Posyandu, Ambulan Ringankan Duka, Program Khitanan; (c) Senyum Mandiri, merupakan program yang menciptakan kebahagiaan dan senyum karena kebehasilan menadapatkan kemandirian ekonomi berkat kepedulian dan dukungan masyarakat (muzaki). Program Senyum Mandiri, terdiri dari: Kelompok Usaha Kecil Mandiri, Sarana Usaha Mandiri, Empowering Centre, Water Well, Pelatihan Skill dan pemberdayaan, Budidaya Agro dan Potensi Lokal; (d) Senyum Ramadhan, merupakan program spesifik yang didasarkan pada waktu yang berkaitan dengan aktivitas-aktivitas bulan ramadhan seperti buka bersama dan lain sebagainya; (e) Superqurban, merupakan 
program optimalisasi pelaksanaan ibadah qurban sesuai dengan syariat dengan mengolah dan mengemas daging qurban menjadi kornet.

\section{LAZ Dompet Dhuafa (DD) Jakarta}

(a) Program Sosial, merupakan program dalam bentuk: Rumah bersalin CumaCuma, Layanan Kesehatan Cuma-Cuma, Klinik Anak Cuma-Cuma, Lembaga Pelayanan Masyarakat yang menangani masalah kesehatan, pendidikan, sandang pangan, transportasi dan ekonomi; (b) Program Pendidikan dan Dakwah, merupakan program dalam bentuk: My Teacher \& program 1000 laptop untuk guru, Beasiswa Pemimpin Bangsa, Pesantren terapis Kesehatan Islami, Training Wirausaha, Da'i Enterpreneur Leader; (c) Program Pemberdayaan Ekonomi, merupakan program pendirian Baitul Maal Wa Tamwil, Sinergi, Bina Usaha Mandiri, Ternakita, Tebar Hewan Kurban; (d) Program Kemanusiaan, merupakan program dalam bentuk DD rescue yang menangani bencana alam dan sosial dan mulai tapan darurat sampai recovery.

\section{Analisis Deskriptif Variabel Penelitian}

Analisis deskriptif data hasil penelitian dapat digunakan untuk memperkaya pembahasan, melalui analisis deskriptif dapat diketahui bagaimana tanggapan responden terhadap setiap indikator variabel yang sedang diteliti. Analisis deskriptif dilakukan mengacu kepada setiap indikator yang ada pada setiap variabel yang diteliti. Agar lebih mudah dalam menginterpretasikan variabel yang sedang diteliti, dilakukan kategorisasi terhadap skor tanggapan responden berdasarkan rata-rata skor penilain responden dengan berpedoman pada tabel berikut:

Tabel 4.3

Pedoman Kategorisasi Rata-Rata Skor Penilaian Responden

\begin{tabular}{|c|c|}
\hline Rata-Rata Skor & Kriteria \\
\hline Kurang dari 4 & Rendah/Kurang baik \\
\hline 4-Kurang 7 & Sedang/Cukup baik \\
\hline 7 atau Lebih & Tinggi/Baik \\
\hline
\end{tabular}

Sumber: Zikmund (2009:377)

\section{Implementasi Total Quality Management secara umum}

Untuk melihat bagaimana implementasi total quality manajement pada LAZ yang diteliti jelas sekali pada kesadaran LAZ untuk selalu melakukan perbaikan secara terus menerus. Secara umum, lembaga pengelola zakat baik LAZ maupun LAZ, telah dituntut untuk melakukan manajemen mutu oleh pemerintah yang diwakili oleh Kementerian Agama. Tuntutan tersebut dalam bentuk penilaian atau akreditasi yang dilakukan setiap tahun. Hal tersebut termaktub dalam Petunjuk Pelaksanaan Akreditasi Organisasi Pengelola Zakat dari Direktorat Pemberdayaan Zakat, Direktorat Jenderal Bimbingan Masyarakat Islam yang diterbitkan pada tahun 2007. Namun penyelenggara sedikit berbeda antara BAZ dan LAZ, untuk LAZ penyelenggara akreditasi adalah Forum Zakat, sedangkan untuk BAZ penyelenggara akreditasi adalah pemerintah bekerjasama dengan BAZ nasional. Selanjutnya, terkait dengan implementasi TQM, terdapat beberapa LAZ yang telah menggunakan berbagai metode International Standard Organization (ISO) maupun metode lainnya,yaitu:

Tabel 4.4

Daftar LAZ Yang Telah Menerapkan Standar Mutu Organisasi

\begin{tabular}{|c|l|l|}
\hline No & \multicolumn{1}{|c|}{ LAZ } & \multicolumn{1}{|c|}{ Standar Yang Digunakan } \\
\hline 1 & LAZ Dompet Dhuafa (DD) & $\begin{array}{l}\text { ISO 9001:2000 dan Standar Mutu Matrix } \\
\text { Achievement }\end{array}$ \\
\hline 2 & LAZ DPU-DT & ISO 9001:2000 \\
\hline
\end{tabular}




\begin{tabular}{|c|l|l|}
\hline No & \multicolumn{1}{|c|}{ LAZ } & \multicolumn{1}{|c|}{ Standar Yang Digunakan } \\
\hline 3 & LAZ Rumah Amal Salman ITB & ISO 9001:2000 dan Standar Mutu Six Sigma \\
\hline 4 & LAZ Rumah Zakat Indonesia & ISO 9001:2000 \\
\hline 5 & $\begin{array}{l}\text { LAZ Al Azhar Peduli Peduli } \\
\text { Ummat }\end{array}$ & ISO 9001:2000 dan Service Excellent \\
\hline 6 & LAZ Nasional Jakarta & ISO 9001:2000 \\
\hline 7 & LAZ Rumah Zakat Indonesia & ISO 9001.2008, Service Excellent \\
\hline 8 & LAZ Bamuis BNI & Standar mutu Six Sigma \\
\hline
\end{tabular}

Sumber: Hasil wawancara dan diolah kembali

Untuk mendukung bahwa banyak LAZ yang telah melaksanakan pengelolaan secara modern dan profesional, seperti: (a) LAZ Dompet Dhuafa sebagai LAZ pertama yang menerapkan manajemen modern dan LAZ terbesar di Indonesia, yang pertama kali menerapkan ISO 9001 dan telah banyak meraih penghargaan dari berbagai institusi seperti: Marketing Award pada tahun 2009 dan 2010 (Dari Majalah Marketing), Social and Enterpreneur Award pada tahun 2009 (dari Ernest and Young), penghargaan dari FoZ sebagai LAZ dengan Muzaki paling banyak yaitu sebanyak 77.000 muzaki; (b) LAZ Al Azhar Peduli Ummat yang mendapat prestasi sebagai: The Best Zakat Empowering Organization pada tahun 2009; (c) Rumah Zakat Indonesia, (1) Islamic Social Responsibility (ISR) Award Maret 2010 (Bidang Social Enterpreneurship Appreciation) dari Majalah SWA melalui Program Senyum Mandiri. (2) Best LAZ berdasarkan survey Majalah SWA dengan indikator Keterpercayaan, Pelayanan dan Rekomendasi terbaik Desember 2010. (3) The Best Fundraising Growth 2010 dari Indonesia Magnificence of Zakat Desember 2010 dan (4) The Best Empowerement in Education Program 2010, dari Indonesia Magnificence of Zakat Desember 2010; (d) Dan masih banyak LAZ lain yang memiliki prestasi yang luar biasa baik di tingkat nasional maupun internasional.

Urgensi penerapan TQM akan tergantung pada masing-masing LAZ, jika LAZ ingin mencapai efisiensi, efektivitas dan kinerja terbaiknya maka TQM menjadi hal yang tidak bisa ditawar. Kesadaran akan implementasi TQM, berawal dari adanya upaya dan tujuan yang berfokus pada pelanggan. Pelanggan LAZ terdiri dari muzaki dan mustahik. Banyak upaya dan usaha yang dilakukan LAZ dalam rangka menciptakan pelayanan yang maksimal dan memberikan kepuasan pada muzaki dan mustahik. Upaya terkait dengan hal tersebut bisa dilakukan LAZ sebagai berikut: (1) Memberikan pelayanan yang cepat dan tepat, dengan menciptakan berbagai cara dan prosedur yang tidak menyulitkan muzaki dan mustahik memperoleh layanan LAZ. Seperti, untuk penghimpunan dana zakat dengan layanan jemput bola bagi ke muzaki oleh amin, bahkan muzaki dipersilakan memilih amil yang disukai, media SMS, internet banking, rekening bank dan masih banyak media lain yang digunakan oleh LAZ dalam rangka mempermudah bagi muzaki dalam menyalurkan dana zakatnya; (2) Akuntabilitas dan transparansi. Konsumen LAZ, telah menuntut LAZ untuk memiliki akuntabilitas dan transparansi yang tinggi. Wujud kedua hal tersebut, LAZ memanfaatkan berbagai media untuk menampilkan wujud akuntabilitas dan transparansi tersebut. Media yang bisa digunakan seperti: media cetak (koran, majalah baik majalah umum maupun majalah organisasi), media elektronik (TV dan radio), internet (hampir semua LAZ miliki web sendiri), anmual report (laporan tahunan) dan masih banyak media yang bisa digunakan dan mudah diakses oleh muzaki dan mustahik; (3) Membangun relasi dengan konsumen. LAZ berusaha menciptakan berbagai program atau kegiatan yang dapat mempererat relasi dengan konsumen. Tujuan kegiatan ini, selain untuk mempertahankan konsumen juga menganggap konsumen sebagai bagian dari organisasi. Kegiatan ini berbentuk; pengajian (untuk berbasis masjid dan ormas), pelatihan (berbasis perusahaan dan LAZ), acara charity, maupun acara 
hiburan dan lain sebagainya; (4) Memiliki dan melaksanakan moto LAZ yang berpihak pada konsumen seperti:

\section{Tabel 4.5}

Moto Beberapa LAZ

\begin{tabular}{|c|l|l|}
\hline No & \multicolumn{1}{|c|}{ LAZ } & \multicolumn{1}{c|}{ Moto LAZ } \\
\hline 1 & LAZ DPU-DT & Menuju masyarakat mandiri ahli dzikir - fikir - ikhtiar \\
\hline 2 & LAZ Nahdlatul Ulama & Zakat untuk kesejahteraan umat \\
\hline 3 & $\begin{array}{l}\text { LAZ Pusat Zakat } \\
\text { Ummat }\end{array}$ & Mengubah mustahik menjadi muzaki \\
\hline 4 & $\begin{array}{l}\text { LAZ Al Azhar Peduli } \\
\text { Ummat }\end{array}$ & Mitra muzaki dan sahabat mustahik \\
\hline 5 & LAZ Dompet Dhuafa & $\begin{array}{l}\text { Caring (Peduli), Networking (Silaturrahim), } \\
\text { Empowering (Pemberdayaan) }\end{array}$ \\
\hline 6 & LAZ Nasional Jakarta & Terdepan, Amanah, Transparan dan Profesional \\
\hline 7 & $\begin{array}{l}\text { LAZ Rumah Zakat } \\
\text { Indonesia }\end{array}$ & $\begin{array}{l}\text { Trusted } \text { Menjalankan usaha dengan } \\
\text { profesional, transparan dan terpercaya }\end{array}$ \\
& $\begin{array}{l}\text { Progressive: Senantiasa berani melakukan } \\
\text { inovasi dan edukasi untuk meperoleh manfaat } \\
\text { yang lebih. }\end{array}$ \\
& c. $\begin{array}{l}\text { Humanitarian: Memfasilitasi segala upaya } \\
\text { humanitarian dengan tulus secara universal } \\
\text { pada seluruh umat manusia. }\end{array}$ \\
\hline
\end{tabular}

Sumber: Data wawancara dan diolah kembali

Moto bagi LAZ dalam rangka untuk memfokuskan semua kegiatan LAZ pada konsumen. Artinya konsumen dilayani dan memperoleh nilai (value) dari LAZ berupa kepercayaan, kepuasan, ketenangan dan pengetahuan. Kemudian, untuk menciptakan pelayanan yang berfokus pada kepuasan pelanggan didukung oleh amil zakat yang memiliki kompetensi dan kapabilitas yang tinggi. Maksudnya keterlibatan amil zakat di semua jenjang aktivitas LAZ menjadi sangat penting dan berarti. Menciptakan keterlibatan amil zakat dalam LAZ bisa dilakukan dengan: (a) Membangun kesejajaran diantara sesama amil zakat. Artinya semua amil zakat dilibat dalam semua kegiatan LAZ sesuai dengan tugas dan tanggung jawabnya. Namun demikian keterlibatan mereka dihargai sebagai bagian dari kesuksesan LAZ. Dalam konteks ini, LAZ memberikan kebebasan bagi amil zakat untuk melakukan inovasi dan kreasi dalam rangka menciptakan program-program yang ditawarkan LAZ. Bahkan untuk LAZ DPU-DT yang memiliki moto bekerja "semua amil zakat adalah bersaudara". Hal tersebut dilakukan dalam rangka untuk membangun kesejajaran dan meneguhkan komitmen bersama dalam melakukan peran masing-masing; (b) Meningkatkan kompetensi dan kapabilitas amil zakat. Banyak hal yang dilakukan oleh LAZ untuk meningkatkan kompetensi dan kapabilitas amil zakat seperti pendidikan dengan studi lanjut dari program S1 dan S2. Selain itu memberikan pelatihan kepada amil zakat menjadi hal yang penting terutama unuk mengupgrade keterampilan. LAZ biasanya mengirim amilnya ke berbagai pelatihan baik yang diadakan oleh FoZ, IMT atau organisasi lain. FoZ biasanya menyelenggarakan pelatihan bagi amil zakat berkaitan dengan aturan, kebijakan dan hal lain yang mengikat semua anggota FoZ yang terkait dengan pengelolaan zakat. IMT biasanya memberikan pelatihan yang berkaitan dengan pengetahuan yang dapat meningkatkan keterampilan amil zakat. IMT banyak memberikan materi berkaitan dengan pembangunan sumber daya manusia (human resources building); (c) Membangun kepercayaan kepada amil zakat dalam melaksanakan tugasnya. Manajemen LAZ sadar, dengan diberikannya kepercayaan yang penuh akan meningkatkan kepercayaan diri pada amil zakat untuk berkreasi, 
berinovasi dan berprestasi. Beberapa LAZ memberikan award bagi amil zakat yang berprestasi. Terbukti, banyak LAZ yang mampu mengkreasi program yang ditawarkan dengan variasi yang tinggi, menjadi keunggulan komparasi dan kompetitif dari masingmasing LAZ.

Untuk bisa menciptakan program yang ditawarkan, tidak hanya harus baik dan memiliki nilai yang tinggi khususnya bagi mustahik, juga harus benar (sesuai dengan syariah). Hal yang harus dilakukan oleh LAZ: (1) mengidentifikasi kebutuhan mustahik; (2) Proses perancangan dan penciptaan program yang ditawarkan dengan mempertimbangkan: manfaat bagi muzaki, instansi yang terkait, siapa yang bertanggung jawab, berapa biayanya, waktu implementasi program dan faktor lainnya; (3) Draft program yang akan ditawarkan LAZ, kemudian dikonsultasikan terlebih dahulu kepada DPS untuk melihat kesesuaian dan kelayakan dari sudut syariah. Artinya pada tahap ini, sudah ada pengendalian kualitas dari proses penciptaan program yang ditawarkan. (4) Setelah diangap sesuai dan layak secara syariah, selanjutnya diimplementasikan dan dimonitor sesuai dengan peruntukkannya; (5) Evaluasi selama program berlangsung maupun program selesai. Hal tersebut dilakukan untuk mengetahui tingkat efektifitas program dan melihat apakah terdapat penyimpangan yang terjadi.

Kemudian, implementasi total quality management yang terdaftar pada FoZ akan terungkap melalui jawaban responden terhadap pertanyaan-pertanyaan yang diajukan pada kuesioner yang mencakup beberapa dimensi. Implementasi total quality management diukur menggunakan 3 (tiga) dimensi dan dioperasionalisasikan menjadi 19 butir pertanyaan.

\section{Implementasi Total Quality Management dilihat dari dimensi variabel penelitian dimensi berorientasi pada kepuasan pelanggan}

Implementasi total quality management pada dimensi berorientasi pada kepuasan pelanggan diukur menggunakan 4 butir pertanyaan. Berikut rekapitulasi rata-rata skor tanggapan responden terhadap keempat butir pertanyaan tersebut.

Tabel 4.6

Rekapitulasi Rata-Rata Skor Penilaian Responden Mengenai Berorientasi Pada Kepuasan Pelanggan

\begin{tabular}{|c|c|c|c|}
\hline Instrumen & Pokok Pertanyaan & $\begin{array}{l}\text { Rata-Rata } \\
\text { Skor }\end{array}$ & Kriteria \\
\hline Pertanyaan 1 & Ketepatan mengidentifikasi konsumen & 8,05 & Tepat \\
\hline Pertanyaan 2 & $\begin{array}{l}\text { Utama mengupayakan kepuasan } \\
\text { konsumen }\end{array}$ & 8,44 & Baik \\
\hline Pertanyaan 3 & Pemahaman penciptaan program & 8,49 & Memahami \\
\hline Pertanyaan 4 & $\begin{array}{l}\text { Upaya menggunakan mekanisme } \\
\text { keluhan konsumen }\end{array}$ & 8,44 & $\begin{array}{c}\text { Menggunakan } \\
\text { Mekanisme Standar }\end{array}$ \\
\hline Total & & 8,36 & Baik \\
\hline
\end{tabular}

Sumber: Kuesioner diolah kembali

Rata-rata total skor penilaian responden pada dimensi berorientasi pada kepuasan pelanggan sebesar 8,36 mengindikasikan bahwa implementasi berorientasi pada kepuasan pelanggan pada sebagian besar LAZ yang terdaftar di FoZ sudah baik. Berdasarkan instrumen, terlihat bahwa LAZ adalah organisasi yang mengandalkan kepuasan konsumen sebagai upaya untuk mempertahankan keberlanjutan. Untuk itu, LAZ menjadikan kepuasan konsumen sebagai kunci keberhasilan LAZ. Upayanya, memiliki pemahaman yang tinggi dalam membuat program yang ditawarkan, ketepatan organisasi dalam memahami kebutuhan konsumen, dan menggunakan berbagai mekanisme dalam berkomunikasi terutama mendengar keinginan dan keluhan konsumen. 


\section{Dimensi pemberdayaan dan pelibatan karyawan}

Implementasi total quality management pada dimensi pemberdayaan dan pelibatan karyawan diukur menggunakan 5 butir pertanyaan. Berikut rekapitulasi rata-rata skor tanggapan responden terhadap kelima butir pertanyaan tersebut.

\section{Tabel 4.7}

Rekapitulasi Rata-Rata Skor Penilaian Responden Mengenai Pemberdayaan dan Pelibatan Karyawan

\begin{tabular}{|c|c|c|c|}
\hline Instrumen & Pokok Pertanyaan & $\begin{array}{l}\text { Rata-Rata } \\
\text { Skor }\end{array}$ & Kriteria \\
\hline Pertanyaan 5 & $\begin{array}{lll}\begin{array}{l}\text { Upaya } \\
\text { berkreasi }\end{array} & \text { memberikan kebebasan } \\
\end{array}$ & 8,24 & Memberikan \\
\hline Pertanyaan 6 & $\begin{array}{l}\text { Upaya memperhitungkan partisipasi } \\
\text { karyawan }\end{array}$ & 8,34 & Memperhitungkan \\
\hline Pertanyaan 7 & Pelatihan dan pengembangan karyawan & 7,85 & Memberikan \\
\hline Pertanyaan 8 & Bentuk kemitraan dengan karyawan & 7,98 & $\begin{array}{l}\text { Menganggap } \\
\text { Sebagai Mitra }\end{array}$ \\
\hline Pertanyaan 9 & Pemberian kesempatan pada karyawan & 8,39 & Memberikan \\
\hline Total & & 8,16 & Baik \\
\hline
\end{tabular}

Sumber: Kuesioner diolah kembali

Rata-rata total skor penilaian responden pada dimensi berorientasi pada kepuasan pelanggan sebesar 8,16 mengindikasikan bahwa implementasi pemberdayaan dan pelibatan karyawan pada sebagian besar LAZ yang terdaftar di FoZ sudah baik. Bila dilihat berdasarkan instrumen, terlihat bahwa amil zakat adalah salah satu kunci keberhasilan bagi LAZ, untuk itu LAZ melakukan pemberdayaan dan pelibatan amil zakat dalam semua aktivitas LAZ dalam melayani masyarakat.

\section{Dimensi pemberdayaan dan pelibatan karyawan}

Implementasi total quality management pada dimensi perbaikan yang berkesinambungan diukur menggunakan 10 butir pertanyaan. Berikut rekapitulasi ratarata skor tanggapan responden terhadap kesepuluh butir pertanyaan tersebut.

Tabel 4.8

Rekapitulasi Rata-Rata Skor Penilaian Responden Mengenai Perbaikan Yang Berkesinambungan

\begin{tabular}{|l|l|c|c|}
\hline \multicolumn{1}{|c|}{ Instrumen } & \multicolumn{1}{|c|}{ Pokok Pertanyaan } & $\begin{array}{c}\text { Rata-Rata } \\
\text { Skor }\end{array}$ & Kriteria \\
\hline Pertanyaan 10 & $\begin{array}{l}\text { Identifikasi masalah jasa yang } \\
\text { disampaikan }\end{array}$ & 7,98 & Mengidentifikasi \\
\hline Pertanyaan 11 & Dikumentasi proses penyampaian jasa & 7,80 & Mendokumentasi \\
\hline Pertanyaan 12 & $\begin{array}{l}\text { Mengukur kinerja sesuai kepuasan } \\
\text { pelanggan }\end{array}$ & 7,88 & Mengukur \\
\hline Pertanyaan 13 & Penyampaian jasa sesuai SOP & 7,98 & Sesuai \\
\hline Pertanyaan 14 & Pemahaman masalah penyampian jasa & 7,90 & Memahami \\
\hline Pertanyaan 15 & Implementasi pemecahan masalah & 7,78 & Baik \\
\hline Pertanyaan 16 & Evaluasi pemecahan masalah & 7,88 & Melakukan \\
\hline Pertanyaan 17 & Pengembangan ide baru & 8,34 & Inovatif \\
\hline Pertanyaan 18 & Evaluasi ide baru & 8,32 & Dievaluasi \\
\hline Pertanyaan 19 & Upaya untuk memuaskan konsumen & 8,61 & Baik \\
\hline Total & & $\mathbf{8 , 0 5}$ & Baik \\
\hline
\end{tabular}


Sumber: Kuesioner diolah kembali

Rata-rata total skor penilaian responden pada dimensi perbaikan yang berkesinambungan sebesar 8,05 mengindikasikan bahwa implementasi perbaikan yang berkesinambungan pada sebagian besar LAZ yang terdaftar di FoZ sudah baik. Bila dilihat berdasarkan instrumen, terlihat bahwa untuk bisa memberikan kepuasan maksimal pada konsumen ternyata tidak cukup pemberdayaan dan pelibatan karyawan, tetapi harus ada upaya perbaikan yang berkesinambungan, dengan melaksankan SOP secara benar dan disiplin, mengorganisasi dan mengevaluasi setiap ide baru dan diujicobakan.

\section{Simpulan}

Hasil penelitian ini menunjukkan implememtasi total quality management (TQM) pada Lembaga Amil Zakat (LAZ) seluruh Indonesia telah baik. Artinya berdasarkan dimensi dari variabel total quality management (TQM) yang terdiri dari Berorientasi Pada Kepuasan Pelanggan, Pemberdayaan dan Pelibatan Karyawan dan Pemberdayaan dan Pelibatan Karyawan. yang diimplementasikan pada lembaga Amil Zakat (LAZ) seluruh Indonesia dengan rekapitulasi rata-rata skor penilaian responden untuk masing-masing dimensi menunjukkan skor yang masuk ke dalam kategori baik

\section{Daftar Pustaka}

Adiwarman A. Karim dan A. Azhar Syarief. 2008. Fenomena Unik Di Balik Menjamurnya Lembaga Amil Zakat (LAZ) Di Indonesia. Makalah disajikan dalam media Jurnal Zakat dan Empowerment Vol 1 Agustus 2008, diterbitkan oleh Indonesia Magnificence of Zakat

Almisar Hamid:2009. Nasib Lembaga Amil Zakat di Indonesia. Artikel ini dimuat pada Harian Republika, Jum'at 05 Juni 2009.

Asep Saefuddin Jahar, Zakat Antar Bangsa Muslim: Menimbang Posisi Realistis Pemerintah dan Organisasi Masyarakat Sipil. Makalah disajikan dalam media Jurnal Zakat dan Empowerment Vol 1 Agustus 2008, diterbitkan oleh Indonesia Magnificence of Zakat (IMZ)

Azyumardi Azra. 2010. Negara dan Pengelolaan Zakat. Makalah ini dimuat pada portal Sekolah Pascasarjana UIN Syarif Hidayatullah Jakarta.

Budi Budiman, 2002, Potensi Dana ZIS Sebagai Instrumen Ekonomi Islam dari Teori dan Implementasi Manajemen. Makalah disajikan dalam Simposium Nasional Sistem Nasional Ekonomi Islam, Yogyakarta.

Circle Of Information And Development (CID) Dompet Dhuafa Republika dan Lembaga Kajian Islam Dan Hukum Islam (LKIHI) Fakultas Hukum Universitas Indonesia.2008. Naskah Akademis Rancangan Undang-Undang Republik Indonesia Tentang Pengelolaan Zakat.

Cooper, D. R, \& Schindler, P. S. (2006). Business Research Methods ( $9^{\text {th }}$ ed.). International edition. Mc Graw Hill.

Creech, Bill.1996. Lima Pilar TQM: Cara Membuat Total Quality Management Bekerja Bagi Anda. Dialihbahasakan oleh Alexander Sindoro. Penerbit Binarupa Aksara. Jakarta

Daniel I Prajogo dan Amrik S Sohal. 2006. The Relationsip Between Organization Strategy, Total Quality Management (TQM) and Organiziation Performance-The Mediating Role of TQM. European Journal of Operational Research: 35.

Djailani, 2003. Strategi Bazis DKI Dalam Menyiasati Implementasi UU No. 38 Tahun 1999 Tentang Pengelolaan Zakat, Forum Zakat (FOZ). 
Fandy Tjiptono dan Anastasia Diana.2001. Total Quality Management. Edisi Revisi. Penerbit ANDI. Yogyakarta

Gunarianto.2005. Pengaruh Penerapan Strategi Keunggulan Bersaing, Total Quality Management, Cost of Quality, dan Sistem Akuntansi Manajemen Terhadap Kinerja Perusahaan. Disertasi. Bandung. Program Pascasarjana Universitas Padjadjaran Bandung.

Hoque Zahirul. 2003. Total Quality Management and The Balanced Scorecard Approach: A Critical

Analysis of Their Potential Relationship and Dirrections for Research. Journal Critical Perspective on Accounting: 563.

Jamil Azzaini.2008. Berdayakan Lembaga Amil Zakat. Artikel ini dimuat dalam Tabloid Republika. Jumat, 19 September 2008

Mulyadi, 1996, Total Quality Management : Pergeseran Paradigma Dalam Pengelolaan Perusahaan, dalam Jurnal Akuntansi dan Manajemen, Edisi Pebruari 1996, Yogyakarta, STIE - YKPN. 2001. Total Quality Management: Prinsip Manajemen Kontemporer Untuk Mengarungi Lingkungan Bisnis Global. Penerbit Aditya Media. Yogyakarta

Samdin, 2002. Motivasi Berzakat: Kajian Manfaat dan Peranan Kelembagaan,. Makalah disajikan dalam Simposium Nasional Ekonomi Islam, Yogyakarta.

2002. "Pengembangan Manajemen Bazis". Makalah disajikan dalam Simposium Nasional Ekonomi Islam, Yogyakarta.

Schermerborn Jr. John R. 1993. Managing for Productivity. Fourth edition. John Wiley \& Son. Inc. New York.

Sekaran Uma.2006. Research Methods For Business. Edisi 4 (Edisi bahasa Indonesia). Buku 1 dan Buku 2. Penerbit Salemba Empat. Jakarta

Soewarso Hardjosoedarmo. 2002. Total Quality Management. Penerbit ANDI. Yogyakarta

Sri Fadilah, 2011. Analisis Pengaruh Implementasi Pengendalian Intern dan Total Quality Management Terhadap Penerapan Good Governance. Hasil riset disajikan dalam Simposium Nasional Akuntansi (SNA) ke-14 di Universitas Syiah Kuala Nangroe Aceh Darussalam Juli 2011, merupakan riset yang didanai LPPM Unisba. Ikatan Akuntan Indonesia (IAI), Jakarta

Susanto. A. A, 2002. "Zakat Sebagai Pengurang Penghasilan Kena Pajak: Sebuah Tinjauan Makro Ekonomi”. Makalah disajikan dalam Simposium Nasional Ekonomi Islam, Yogyakarta.

Tenner, Arthur R and Detoro Irving J. 1993. Total Quality Management. Adison-Wesley publishing company. USA.

Undang-Undang No 38 Tahun 1999 tentang Pengelolaan Pajak 